\title{
Outcomes Assessment in Undergraduate Information Literacy Instruction: A Systematic Review
}

\author{
Allison Erlinger
}

\begin{abstract}
There is a well-established need for academic libraries to demonstrate their impact on student learning, particularly through the application of measurable outcomes in information literacy instruction (ILI). Recent literature is replete with articles both outlining the importance of welldesigned assessment as an integral part of ILI and providing examples of the methods being used at particular institutions. This review synthesizes the theoretical and practical literature on ILI assessment in an effort to answer three questions: What do we know about assessment methods and what general recommendations exist? What assessment methods are academic librarians actually using? How does professional practice compare to existing recommendations?
\end{abstract}

\section{Introduction}

During the last two decades, both information literacy and outcomes-based assessment have come to the forefront of higher education. It is widely acknowledged in the literature that assessment has become a focus in all areas of higher education; instructional departments can no longer assume that students are learning-administrators and accrediting agencies alike demand to see real evidence of student learning and the ability to apply skills in real-world situations. ${ }^{1}$ Subsequently, according to Tancheva, Andrews, and Steinhart, "there has been a shift in emphasis from inputs and outputs ...to users and outcomes."2 Furthermore, Grassian and Kaplowitz explain that, in an era of financial constraint, all academic departments, including libraries, need to justify their expenses through assessment or risk having their programs terminated. ${ }^{3}$

Likewise, Oakleaf, Millet, and Kraus emphasize that information literacy, defined by the Association of College \& Research Libraries (ACRL) as the ability to "recognize when information is needed and have the ability to locate, evaluate, and use effectively the needed information," is a crucial skill in all academic disciplines, as well as in the working world. ${ }^{4}$ In their 2012 literature review, Schilling and Applegate explain that, during the 1990s, higher education accrediting agencies began to adopt information literacy competencies as indicators of academic success, and the ACRL began developing the Information Literacy Competency Standards for Higher Education, demonstrating the

*Allison Erlinger is a Reference Librarian at the Nationwide Children's Hospital Grant Morrow III Medical Library; e-mail: Allison.Erlinger@nationwidechildrens.org. (C2018 Allison Erlinger, AttributionNonCommercial (http://creativecommons.org/licenses/by-nc/4.0/) CC BY-NC. 
growing focus on this vital skill set. ${ }^{5}$ Oakleaf, Millet, and Kraus also report, however, that graduates continue to demonstrate underdeveloped information literacy skills, while overestimating their own capabilities in this area. ${ }^{6}$ Subsequently, there has been a growing trend, reported in a number of the articles reviewed here, toward incorporating information literacy competencies into various academic disciplines. ${ }^{7}$ Oakleaf and Kaske discuss the increasing involvement of librarians in the accreditation process through the demonstration of their contribution to the development of information literacy skills and the production of quality graduates. ${ }^{8}$ The most effective means of achieving this goal is through the application and reporting of quality assessment practices; but, in a separate 2008 article, Oakleaf confronts the fact that many librarians feel unprepared to meet this challenge. ${ }^{9}$

A brief review of the history of library instruction provided by Grassian and Kaplowitz in their 2009 book demonstrates that we have come a long way from library skills-based bibliographic instruction toward a more global information literacy and research-focused approach, integrating several of the forward-looking strategies developed by pioneers like Evan Farber and Miriam Dudley with new technologies and developing teaching/learning approaches. ${ }^{10}$ This broader and more integrated approach to ILI calls for the use of more robust assessment techniques to demonstrate its impact.

Three primary functions of information literacy instruction assessment clearly emerge from the literature and are specifically listed in several of the items reviewed here: providing feedback to learners; providing feedback to instructors; and demonstrating the value of programs to stakeholders and administrators. ${ }^{11}$ Assessment can show learners where they have improved and where they need further development, as well as contributing to the learning process itself. It lets instructors know whether teaching was successful, helps them determine the efficacy of their methods, and contributes to ongoing program development. In an era of rapidly spreading austerity measures, assessment can demonstrate the value of and continued need for library instruction programs to administrators, accrediting agencies, government bodies, parents, and learners themselves.

As Blanchett, Webb, and Powis note in the introduction to their 2012 book, "there is a huge amount about information literacy published every year, ranging from theoretical overviews of the nature of information literacy to case studies of the applications of different pedagogical approaches." ${ }^{12}$ What is lacking, however, is focused synthesis of this growing body of literature, bringing together what we know about assessment with what academic librarians are actually doing, in an effort to determine where we stand as a professional whole. If we want to use assessment to its full potential in the continued development of and support for ILI programs, we need to know not only that we are doing it, but also that we are doing it well. We need to assess our assessment practices and determine whether they are living up to the potential that research has shown to exist. This review synthesizes recent professional literature on assessment theory and methodology with published reports of ILI assessment carried out by librarians at four-year institutions and compares the two to determine whether our professional practice is meeting its potential.

\section{Literature Review}

In a review of assessment methods used in libraries from 2007 to 2012, Schilling and Applegate identified the most popular methods used; the pros and cons of each; and the relationship between measures of attitudes, skill, and behavior. They reported that affective measures were more common than measures of skill and behavior, despite not being reflective of actual learning outcomes. ${ }^{13}$ In that same year, Sobel and Sugimoto 
conducted a nationwide survey of academic instruction librarians asking who they assess, how they assess, what they do with the data collected, and what assessment skills they would like to develop. Their findings demonstrated that in-session worksheets were the most common assessment, followed by "quizzes," and finally analysis of graded student assignments. ${ }^{14}$ Now, four years later, this review reconsiders the methods being used to determine whether practice has changed and how it compares to recommendations present in the theoretical literature.

As much of the literature on ILI assessment and many of the assessment tools themselves are grounded in a series of documents published by the ACRL, a brief review of these publications is warranted. In 2000, the ACRL released the Information Literacy Competency Standards for Higher Education (the Standards), which serve as a guide for assessing information literacy in individuals. The Standards provide the structure for various ILI and assessment techniques and are referenced in the majority of items reviewed here. ${ }^{15}$

In the following year, 2001, the ACRL released an updated Model Statement of Objectives for Information Literacy Instruction (the IS Objectives; originally published in 1987). The IS Objectives are mapped onto the five Standards and are designed to be used in defining terminal learning objectives that are broken down into discrete measurable units. ${ }^{16}$ Completing this set of publications is the Characteristics of Programs of Information Literacy that Illustrate Best Practices, published in 2003 and revised in 2012. This document presents best practice recommendations for information literacy instruction in ten discrete categories and is intended for use in the development, assessment, and improvement ILI programs. ${ }^{17}$ In January 2016, the ACRL replaced the Standards with the new Framework for Information Literacy for Higher Education (the Framework), which focuses on higher-level concepts instead of the enumeration of specific skills. ${ }^{18}$ Having only recently been adopted, the Framework is not yet reflected in the published literature on ILI assessment reviewed here, but will likely begin appearing in forthcoming publications on the topic.

\section{Research Methods}

This review includes literature that presents both research on ILI assessment in general, including description and evaluation of specific assessment methods (the theoretical literature), and case reports of assessments used in practice at particular institutions (the practical literature). Although I have not included technical, professional, and governmental reports in my official review, the ACRL publications inform library ILI generally and provide the foundation on which the literature, theory, and practice are built, and so are included only in the literature review.

The items included in this review were gathered through a process of database searching, bibliography mining, and the inclusion of known items. A series of six searches was carried out in the Library, Information Science, \& Technology Abstracts (LISTA), and Library Literature databases, using the EBSCOhost search interface. The searches included all possible combinations of the following terms, representing the concepts of ILI and outcomes assessment, respectively: ${ }^{19}$

- SU library orientation for college students; SU information literacy-study and teaching; SU information literacy - research; SU libraries and education; library instruction; information literacy instruction

- $\quad$ SU pre- \& post-tests; SU authentic assessment; SU competency tests; SU educational assessment; SU self-evaluation; SU instructional effectiveness; SU scoring rubrics; SU alternative assessment; outcome* assessment; outcome* measurement*; assess ${ }^{*}$; evaluat ${ }^{*}$; measur* learning outcome ${ }^{*}$; education ${ }^{*}$ outcome* 
These searches resulted in a total of 3,331 initial results. After deduplication and screening using the inclusion and exclusion criteria described below, 73 items were retained. Bibliographic mining and the inclusion of known items resulted in the addition of 29 items, for a total of 102 items included in the review. Because the initial result set was quite large, relatively restrictive criteria were applied for publication type, geographical area, and ILI format/target audience to narrow the field to a manageable size. Because it is my intent, however, to be as comprehensive as possible within the present constraints and to consider trends over time, I selected a time period of ten years, which encompasses the time covered by Schilling and Applegate in their 2012 review (2007-2012), and the year in which Sobel and Sugimoto conducted their survey of instruction librarians, as well as an additional five years. The inclusion and exclusion criteria applied are as follows:

\section{Inclusion}

- Items discussing assessment of library/information literacy instruction in higher education, specifically among traditional four-year undergraduates in the United States and Canada

- Primary focus on assessment of face-to-face instruction at the classroom level

- Published since January 2006, in English, in Library and Information Science journals

- In case reports, instruction provided primarily by librarians, and items either focusing primarily on assessment or including a dedicated assessment section

\section{Exclusion}

- Instruction primarily delivered online and/or at the program or institutional level (for-credit courses and campuswide curricular initiatives)

- Instruction given to other populations (graduate/professional programs, community colleges, primary/secondary education)

- Grey literature: conference papers/proceedings, posters, dissertations, technical/ government reports, self-published

Included items were entered into an Excel spreadsheet and categorized as theoretical (43 items) or practical (59 items). Items including components of both were categorized according to the predominant topic, so that each was included in only one category. Appendix A provides a table of items included in the review by category (theory or practice). Further categorizations were defined through an initial review of the theoretical literature, and each item was then coded for the type of instruction (when appropriate), the primary type(s) of assessment described or used, and presence or absence of four additional constructs. As each item was read, the pertinent information was entered into the workbook, which was later used for sorting and basic calculations.

\section{Findings}

The options available when selecting an assessment method are many and are defined and grouped in a number of ways. For the purpose of this review, I have identified the following seven general assessment types: surveys, focus groups, objective tests (locally developed), classroom assessment techniques (CATs)/performance measures, authentic assessment, rubrics, and standardized tests.

Much of the theoretical literature on ILI assessment, however, also employs higherlevel frameworks for organizing different methods across a set of dimensions to summarize and compare them. These frameworks do not describe discrete methods of assessment but rather group existing methods based on how they are used or what type or learning they measure. I will employ two such frameworks for richer descrip- 
tion of the assessment types discussed: formative versus summative assessment and Kirkpatrick's four levels of assessment.

The formative versus summative framework distinguishes assessment activities based on when and how they are used within the context of an instruction session. Some confusion about this framework and misapplication of terms are present in the practical literature, but the construct is clearly defined in general educational literature, having roots in both the cognitive and social constructivist theories developed in the mid-nineteenth century. ${ }^{20}$ Formative assessment is assessment that happens during instruction; it is often informal and provides immediate feedback to both the instructor and the students to improve teaching and learning as it is happening. ${ }^{21}$ Students can make corrections and try again in a low stakes environment, as formative assessments are not typically graded..$^{22}$ Instructors can gauge their own effectiveness and then "repeat, reinforce, or rejoice" as appropriate. ${ }^{23}$ In contrast, summative assessments tend to occur after learning is complete; they are often formal, cumulative, and designed to provide a comprehensive picture of student learning after a program of instruction and are used to improve teaching and learning after the fact. ${ }^{24}$ Although it may appear that the two approaches are mutually exclusive, they can be used in conjunction and build on one another over the course of an entire information literacy program (for example, an annotated bibliography could be a summative assessment in a beginning course that is later used formatively for the development of a research paper). ${ }^{25}$

The second major framework, Kirkpatrick's Four Levels of Assessment, categorizes assessment activities based on what instructors are trying to find out about their students. It was initially developed by Donald Kirkpatrick in the mid-nineteenth century and is widely accepted and used by training professionals in a variety of fields. ${ }^{26}$ Across several works, Grassian, Kaplowitz, and Veldof have usefully applied this framework in the context of ILI assessment. ${ }^{27}$ Each of Kirkpatrick's four levels has a discrete assessment goal phrased as a simple question and lends itself to certain assessment methods:

Level 1: Reaction-Did they like it? These assessments are perception-based methods that determine whether learners enjoyed the instruction, environment, and teaching methods and whether they believe they learned anything from it. They frequently take the form of surveys or questionnaires that measure affective, rather than cognitive, learning - they tell us about students' feelings, attitudes, and perceptions, but not what they have learned. ${ }^{28}$

Level 2: Learning - Did they get it? These assessments measure learning in a controlled, simulated, and/or hypothetical environment. They typically take the form of either performance assessments or knowledge tests that challenge students to apply what they have learned, but still within the context of the instruction program. Although they do measure what students have learned, they do not reflect how the learner would react in a real-world situation..$^{29}$

Level 3: Behavioral-Can they do it? These assessments attempt to determine whether the students' methods of real-world problem solving have changed as a result of the instruction; they ask learners to apply what they have learned outside the context of instruction. This type of assessment provides insight into the students' capability to produce a desired end result but does not reflect the process involved in doing so. ${ }^{30}$

Level 4: Results-Does it matter? These assessments consider the big picture and long-term effects of instruction - they attempt to determine whether the instruction had any effect on the life of the students. They may take the form of measuring the four-year retention rates or graduation GPAs of students who received IL instruction or consider the types of jobs obtained by graduates who did and did not receive instruction. Due to the difficulty in carrying out such assessments, they are rarely done in the ILI context. ${ }^{31}$ 
In addition to formative and summative assessment, discussed above, there are a number of other terms that are inconsistently applied in the practical literature and warrant clarification. There appears to be a lack of consensus on whether performance and authentic assessments are in fact distinct from one another. Carter acknowledges the disagreement present in scholarship and elects to consider them one construct, which she terms "authentic," while others use the terms interchangeably. ${ }^{32}$ In this review, I maintain the distinction between performance and authentic assessments: namely, that performance assessments are simulated scenarios in which students are asked to demonstrate learning in low-stakes situations, usually ungraded, in-session activities or assignments, while authentic assessments require students to demonstrate learning in real-life situations - they are often tied to graded course assignments or those that the students complete outside the context of the ILI session. ${ }^{33}$

Another pervasive terminological issue is the lack of distinction between the terms test and survey. According to the theoretical literature, surveys, a Level 1 assessment, are strictly subjective and reflective in nature. Tests, on the other hand, are Level 2 assessments that ask objective questions assessing respondents' knowledge of the subject matter. In the practical literature there is a tendency to switch or use these terms interchangeably. ${ }^{34}$ In this review, I use the terminology as defined in the theoretical literature regardless of how the individual authors refer to their methods.

Finally, the definitions of one-shot and course-embedded ILI require clarification. In this review, I classify any ILI that occurs in a single session, whether in the context of a particular course or separately, as one-shot ILI, while more than one session delivered as part of an academic course is considered a course-embedded series. There were no reports of multiple sessions occurring outside the context of an academic course. Two reports classified as "other" present special circumstances that will be described in more detail below. What follows is a summary of my findings organized using the seven types of assessment identified above (surveys, focus groups, objective tests, CATs/performance assessments, authentic assessment, rubrics, and standardized instruments).

Overall, the most frequently reported method of assessment is CATs/performance assessment, which was used in slightly more than half of the case reports, followed by surveys, authentic assessment, objective tests, and focus groups, in that order. Almost half $(46 \%)$ the cases reviewed report the use of multiple methods, and one-quarter $(25 \%)$ report the use of rubrics. It is important to note that, due to the use of multiple methods in many cases, the totals reported do, in some cases, exceed 59 (the number of practical items reviewed).

\begin{tabular}{|l|c|c|}
\hline \multirow{3}{*}{ TABLE 1 } \\
Overall Frequency of Methods Used \\
\hline \multirow{2}{*}{$\begin{array}{c}\text { Assessment } \\
\text { Method }\end{array}$} & \multicolumn{2}{c|}{ Frequency of Use } \\
\cline { 2 - 3 } & Percent & Total Number \\
\hline CATs/Performance & $53 \%$ & 31 \\
\hline Survey & $49 \%$ & 29 \\
\hline Authentic & $41 \%$ & 24 \\
\hline Objective Test & $34 \%$ & 20 \\
\hline Focus Group & $5 \%$ & 3 \\
\hline Rubric & $25 \%$ & 15 \\
\hline Multiple Methods & $46 \%$ & 27 \\
\hline
\end{tabular}

\section{Surveys}

- Formative or summative

- Level 1: Reaction

Surveys are used to gather demographic data and assess the attitudes, opinions, and feelings of students. Surveys do not measure whether or what students have learned but rather what they liked or disliked about the instruction and/or whether they believe they have learned anything. In this way, surveys tend to measure the affective rather than cognitive or behavioral domains of learning. This does not mean, however, that they are 


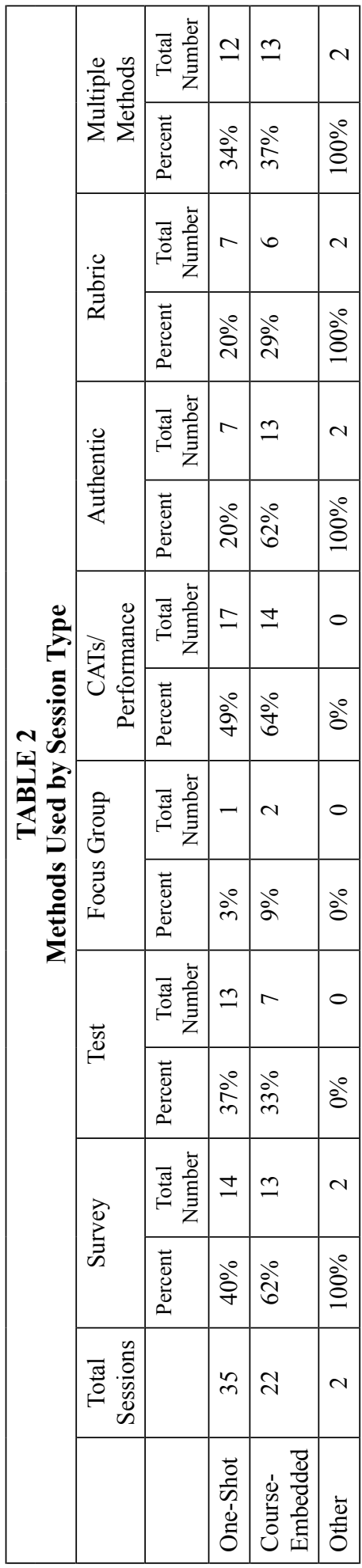

not useful assessment instruments. Students' reactions to a session can provide valuable feedback for revision in future sessions in terms of delivery mode, environment, pace, and tone, among other aspects. ${ }^{35}$ Surveys can also measure self-perception of learning and skill level, but these data should be approached with the knowledge that students often overestimate their own information literacy skills. ${ }^{36}$

Purposeful measurement of the affective domain can also be an assessment goal of its own, though it is little discussed in the literature. This review uncovered two articles that discuss affective assessment, both of which assert that the affective domain of learning is just as important as the cognitive and behavioral, though it receives considerably less attention. ${ }^{37}$ According to Cahoy and Schroeder, the motivations and emotions of students, coupled with the well-established concept of library anxiety, make affective assessment vital to the development of information literacy. Surveys are a popular and relatively easy way to assess the affective domain, though, like the other domains of learning, the affective domain is best assessed through direct observation whenever possible. ${ }^{38}$

The strengths of surveys include: ease of administration; ease of scoring and comparison; good measure of perceived self-efficacy; low cost; quick to administer; useful feedback to instructors. Surveys and questionnaires also have the following weaknesses: they do not measure learning; students often overestimate their own skills; they focus on intentions not behavior; students may tell us what we want to hear; they often provide little depth or detail in responses. ${ }^{39}$

Approximately half (49\%) of the case reports reviewed included the use of surveys as an assessment method. Five reports included the use of surveys to gain feedback on the content and delivery of the ILI session. ${ }^{40}$ Far greater numbers of reports, however, included the use of surveys as measures of students' confidence in their own IL skills and self-report of information behavior, either in the past or planned (what they will/would do in a future situation). ${ }^{41}$

The vast majority of authors report using surveys in a pre-/post-session design, but three also used longitudinal post-post-session surveys to measure long-term effects of ILI on students' attitudes and reported behavior. ${ }^{42}$ Ferrer-Vinent and Carello administered a survey to participants in a course-embedded biology ILI program three 
years later, when the students, who were freshmen at the time of the ILI program, were preparing to graduate. While most of the surveys measured student reactions to ILI sessions, several reports also included the use of surveys among the course faculty in whose classes the ILI sessions were delivered. ${ }^{43}$

\section{Focus Groups}

- Summative

- Level 1: Reaction

Focus groups are not widely covered in the literature, but they do constitute a major category of assessment that merits discussion. These are facilitated, structured conversations with groups of respondents. Focus groups allow for open-ended discussion of affective components, processes, and skills, but they cannot measure learning or behavior as they are based entirely on self-report. They can, however, provide rich descriptive data when well constructed and properly facilitated. ${ }^{44}$ When using focus groups, it is important to keep in mind that differences in age, language, and culture can present difficulties; focus groups naturally involve group dynamics that can skew the conversation in a certain direction, even if not all participants are actually in agreement. ${ }^{45}$

Focus groups have the following strengths as an assessment method: ability to ask follow-up or clarification questions; ability to collect data from several participants at once; the generation of rich descriptive data; can provide unexpected results not accounted for in other forms of assessment. The weaknesses of focus groups include: require a great deal of time to administer; difficult to synthesize and code results; require training for good facilitation; learners may be uncomfortable expressing true opinions and tell us what we want to hear. ${ }^{46}$

By far the least reported method, focus groups were used by the authors of only three case reports reviewed. Because the few authors who used focus groups each did so in a very different way, this section includes detailed individual summaries rather than a collective overview of focus group use. Watson et al. used focus groups (in addition to CATs and surveys) to obtain feedback from students following their ILI sessions. ${ }^{47}$ Spackman employed focus groups as a part of a fully embedded IL program in a large undergraduate biology course. In addition to the whole class lectures, teaching assistants (TAs) ran smaller sessions in which the IL component was embedded. Spackman conducted focus groups with the TAs, rather than the students in the course, to gain feedback on the IL program. Because many of the TAs were themselves undergraduate students, they too benefited from the IL program and provided useful feedback to the librarians. ${ }^{48}$ Finally, Bowles-Terry conducted focus groups with graduating seniors and asked them to reflect on the long-term impact of ILI sessions during the course of their college careers. The feedback from these sessions was largely positive, and some unexpected findings were uncovered. The students found useful the ILI they had had and expressed a desire for more ILI. They suggested a tiered format for ILI, with increasing detail and depth as students progress. Students who had transferred from other institutions - a group not elsewhere encountered in the literature reviewed-expressed a desire for special ILI sessions upon their arrival on a new campus. Students also expressed a fondness for course-specific LibGuides and wished that more of them had been available. ${ }^{49}$

\section{Objective Tests_Locally Developed}

- Formative or summative

- Level 2: Learning

Objective tests are the basis of traditional assessment and include instruments that ask students a series of questions based on what they have been taught and have 
predetermined correct responses..$^{50}$ I have specified "locally developed" here to distinguish this category from the standardized tests that constitute a separate category. Objective tests can include fixed-choice and/or open-ended items. Fixed-choice items include multiple-choice, true/false, and matching-type questions; open-ended questions may be short answer, fill-in-the-blank or essay style. In any case, the test designer has predetermined a set of correct answers against which the answers of the student will be measured, though open-ended questions do provide richer data than fixed-choice questions. ${ }^{51}$ Tests can be given anytime during the session, but they are most frequently applied as pretest only, pre-/post-test combination, or post-test only. Regardless of their specific design and timing, objective tests measure only what students know, not what they can do. ${ }^{52}$ Oakleaf suggests that objective tests are good for identifying gaps in the existing knowledge of students: that is, tests are better at telling us what students don't know rather than what they do. ${ }^{53}$

Although they can be used formatively or summatively, objective tests tend to be employed as summative assessments. Andrea Brooks, however, describes the use of a pretest-only formative assessment model grounded in constructivist learning theory. ${ }^{54}$ In this model, a review of the pretest is incorporated into the session and short-answer questions are used as discussion points. This example demonstrates the flexibility of even the most traditional assessment tool and the opportunities afforded by creative application of assessment.

The primary strengths of objective tests are: ease of administration; ease of grading; low cost; efficient assessment of a large number of students; generation of easily reportable numeric data; familiarity and comfort on the part of administrators and stakeholders; high reliability. Weaknesses of objective tests include: lack of authenticity; do not measure higher-order skills; can be time-consuming to create; measure recognition rather than recall; oversimplify concepts; usefulness can be threatened by teaching to the test; issues of vocabulary and culture can interfere. ${ }^{55}$

Objective tests are used both formatively and summatively, typically in a pre-/posttest design, in which the pretest results are used to drive the content of the session and as discussion points for review concepts that have been identified as problematic. Of the 20 case reports that included objective tests, 17 specifically report employing a pre-/ post-test design, and 1 reports using a post-post-test to measure retention over time. ${ }^{56}$ All reports used locally developed test items, but only Scales and Von Seggern provide the details of validity testing, for which they employed external experts. ${ }^{57}$ Staley et al. developed a pool of standardized questions from which IL instructors could select based on the specific content of their sessions. ${ }^{58}$ The majority of objective tests were given on paper or using a student response system either during the IL session or in class sessions immediately preceding or following it. Smale and Regalado and Dennis et al., however, used the Blackboard course management system to administer tests outside of class time. ${ }^{59}$ Arguably the most creative application of objective tests was reported by Johnson et al., who assigned students a take-home group exam that included a mix of standard objective items and performance-based questions. ${ }^{60}$

\section{Classroom Assessment Techniques (CATs) and Performance Measures}

- Formative

- $\quad$ Level 2: Learning

CATs were first defined by Angelo and Cross in late 1980s and use active learning and formative assessment to get a snapshot of students' grasp of the material while it is being presented. ${ }^{61}$ CATs take many forms and can be used at any point during a session to provide immediate feedback to students and instructors alike. These activities can also increase the energy level and engagement of an audience whose attention seems 
to be flagging. Early methods included the one-minute paper or muddiest point, in which students are asked to quickly write down the most important lesson they have learned or least clear concept that has been introduced. Other examples are observing and questioning students as they work in small groups, one-sentence summaries, and in-session worksheets. ${ }^{62}$

More recently, student response systems ("clickers" and the Poll Everywhere website/ mobile app) have been introduced as a new tool for CATs, using technology to engage and assess students on the spot but without high stakes. Such tools ask a question of the entire group and immediately display aggregate response data on a screen. While they are still under study and initial reactions are mixed, some users have reported that such systems increase energy and engagement, spur discussion, and help instructors identify points that need review. ${ }^{63}$ CATs have been found to be especially useful in one-shot sessions where time is limited and opportunities for application and review of authentic and summative assessments are few. ${ }^{64}$

I am also including performance measures here, as they tend to take the form of activities completed during instruction and for which feedback is provided apart from course assignments and grades. Performance assessments are activities that require students to apply what they have learned in simulated real-world scenarios. They may take the form of instructors observing the students as they perform a task or examining the product of a performance task and judging its quality. An example might be asking students to identify three potential sources on a given topic and generate a brief annotated bibliography. Like other CATs, performance assessments are an active "assessment for learning" approach. ${ }^{65}$

CATs and performance measures have the following strengths as assessment tools: immediate feedback; contributions to learning; ability to capture higher-order skills; valid data; giving students a realistic picture of skill set while there is still time to adapt; quickness of administration; acting as "assessment for learning"; low cost. Weaknesses of CATs include: difficult to measure, code, and quantify; information gathered is very broad; have limited generalizability to other settings; can be time-consuming to create. ${ }^{66}$

The most frequently reported type of assessment, appearing in 31 of the 59 case reports, CATs and performance measures are generally formative in nature and measure learning and/or behavior (Kirkpatrick Levels 1 and 2). Although these assessments take many forms, in-session worksheets are the most commonly reported CAT/performance assessment, used in 10 of the case reports. Worksheets are most often locally developed instruments that are tailored to the particular situation and can take a wide variety of forms. ${ }^{67}$ Various in-session activities and student response systems (SRS or "clickers") constitute the next most frequently reported categories of CATs/performance assessment, with seven and six reports respectively. ${ }^{68}$ Traditional CATs, such as one-minute papers and the muddiest point, were reported four times; ${ }^{69}$ the use of group work with a roving librarian who could ask and answer questions of the students was included in three reports. ${ }^{70}$

There were also four unique applications of the CAT/performance method, demonstrating the flexibility and opportunity for creativity provided by this kind of assessment. Gross et al. reviewed a series of paper drafts that were ungraded and allowed for progressive assessment of learning and improvement over a series of sessions integrated into an upper-level mathematics writing course.${ }^{71}$ In another application, an interactive Jeopardy! game was developed and used during IL sessions to engage students, assess learning, and provide on-the-spot correction when needed. ${ }^{72}$ Byerly, Downey, and Ramin employed a locally developed web-based performance exercise set (called LISA) to assess students in a pre-, post-, and post-post-test design. Because LISA is performance-based (rather than a set of objective questions) and was used in 
a low-stakes manner (not contributing to a grade), it is counted among the creative applications of performance assessment. ${ }^{73}$ Finally, a low-stakes website evaluation and attribution exercise was used to compare the performance of students who had and had not received a one-shot information session in a previous course. ${ }^{74}$

\section{Authentic Assessment}

- Formative or summative

- Level 3: Behavioral

Authentic assessments are those that challenge students to apply what they have learned in real-life situations; they are often purposefully "ill-defined challenges" that reflect the ambiguities and complexities of real-world problems. ${ }^{75}$ Because these tasks are often purposefully vague in order to measure complex skills, careful delineation of criteria for assessment is essential and often a rubric is employed for this purpose. ${ }^{76} \mathrm{It}$ is generally agreed that authentic assessments are most effective when tied to an existing, graded course assignment, as this is a real-life task that fosters student motivation. ${ }^{77}$

Of all the assessment methods reviewed, authentic assessments provide students with the most latitude in how they approach the assigned task. Examples of authentic assessments are portfolios, course-based research papers, bibliographies submitted for citation analysis, and research logs ${ }^{78}$ Authentic assessments can be used formatively if assessment occurs piecemeal throughout the development process, or summatively if only a final product is assessed after completion. Authentic assessments that are tied to existing course assignments are very difficult to use in one-shot sessions and require a high level of collaboration with academic faculty, which can present a challenge for implementation. ${ }^{79}$ Tasks that are related to, but separate from, course assignments, such as research logs, worksheets, or journals that document the process of creating a final paper or project can also be difficult to implement because students may see them as extra busywork on top of their primary assignment. ${ }^{80}$

The benefits of authentic assessment include: contextualization of assessment; high validity; measurement of higher-order skills; demonstration of behavior change; easily aligned with existing instructional goals; account for different learning styles; provide direct evidence of learning; students know the expectations in advance; foster motivation and engagement. These assessments also have their own particular weaknesses: very time-consuming for students to produce and for instructors to score; require high degree of faculty collaboration; difficult to determine how students approached the problem and if they received outside help; require the development of clear grading criteria or scoring can be subjective and unreliable. ${ }^{81}$

In the case reports reviewed, authentic assessment was used in an exclusively summative manner in 24 of the 59 cases. This method was overwhelmingly applied to graded course assignments already assigned by academic faculty. ${ }^{82}$ Only Moreton and Conklin report using an assignment that was not an existing part of the academic course, but that was counted as part of the grade after being included by the librarian IL instructor. ${ }^{83}$ In many cases, the final course paper and/or bibliography were used as the object of assessment. ${ }^{84}$ Two groups of authors assessed research logs that were completed alongside final course projects in their authentic assessments. ${ }^{85}$ Rubrics were used by several of the authors and will be discussed in a separate section below.

Although it is not specifically listed as an authentic assessment technique, I include here four reports of Level 4 assessment. Vance, Kirk, and Gardner compared the endof-year GPAs and retention rates from freshman to sophomore year between students who had and had not participated in ILI sessions as freshmen..$^{86}$ Bowles-Terry compared the cumulative GPAs of graduating seniors who had and had not been given ILI instruction, and Coulter, Clarke, and Scamman compared the final course grades 
of students in different sections of the same course who had or had not received ILI as part of that course. ${ }^{87}$ Squibb and Mikkelsen assessed both the final course grades and semester GPAs across course sections. ${ }^{88}$ In all four cases, the results were relatively disappointing and complicated by a range of factors that could not be controlled for, highlighting the challenges this type of assessment presents.

\section{Rubrics}

- As a flexible tool rather than an assessment method, rubrics cannot be assigned any specific type or level of assessment

Rubrics are a tool that can be applied to various types of assessment rather than a discrete method in themselves. They are so widely covered in the theoretical literature, however, that they warrant separate discussion. Rubrics are descriptive scoring schemes that guide analysis of student work; they describe and define set levels of performance on a given task, as a whole or in component parts, and provide specific and consistent criteria against which various artifacts of learning can be measured. ${ }^{89}$ Rubrics tend to take the form of tables listing a set of criteria, specific indicators for the criteria, and clearly defined proficiency levels for each criterion.

Rubrics are incredibly flexible tools: they can be holistic (considering the entire learning artifact together) or analytic (considering parts of the artifact separately and tallying up the scores); they can be based on verbal indicators of proficiency (for example, "below proficient, proficient, advanced") or numeric scales (assignment of a number between 1 and 5 on each indicator); they can be applied to a variety of learning artifacts including open-ended test questions, performance assessments (worksheets, one-minute papers, bibliographies, and the like), and authentic assessments (papers, portfolios, research logs, and so on)..$^{90}$

Rubrics can provide very reliable assessment results, but they can be difficult and time-consuming to develop and use effectively. To be effective, rubrics must be tailored to the situation, aligned with learning outcomes, tested for validity, calibrated, and normed to improve reliability. To help break down this daunting task and provide it with a more digestible structure, a multiyear project known as RAILS (Rubric Assessment of Information Literacy Skills) was undertaken to facilitate the development of quality rubrics at nine institutions of higher education and produce training artifacts that can be used independently in the creation of rubrics. ${ }^{91}$ Since then, Holmes and Oakleaf have published a guide to rubric norming, the process through which those who will be responsible for applying the rubric are trained to use it consistently. ${ }^{92}$

When properly developed and used, rubrics have very broad applicability and can provide rich, reliable feedback to students and data for instructors. Like any instrument, rubrics have their own set of strengths and weaknesses. The strengths of well-designed rubrics include consistency in scoring; efficiency in scoring; the development of a set of agreed-upon learning values; encouragement of meta-cognition and self-reflection; direct and meaningful feedback. The primary weaknesses of rubrics are: challenging and time-consuming to create and norm; training required for use; reflect the product, not the process. ${ }^{93}$

A total of fifteen reports included the use of rubrics, but only five specified that reliability and/or validity testing was done prior to implementation. ${ }^{94}$ Five reports also discussed the norming processes used with their locally developed rubrics, ${ }^{95}$ and two reported using resources made available on the Project RAILS website during their development. ${ }^{96}$ The majority of rubrics were used in the scoring of authentic assessments, primarily final papers and bibliographies. ${ }^{97}$ Rubrics were used in a variety of ways including scoring worksheets and answer sheets for an interactive activity and, in a good demonstration of their flexibility, as a scoring tool for an objective test 
in an effort to gain a more comprehensive picture of student performance in three subcategories of IL. ${ }^{98}$

Rubrics were also used in both reports classed as "other" session types in this review. Julie Gilbert, in addition to pre-/post-session surveys, used a rubric in her comparison of the final paper bibliographies of students in nine different sections of the same required freshman seminar course, four of which had a one-shot ILI session and five of which had multiple sessions over the course of the semester. ${ }^{99}$ Helms and Whitesell report on the progression from a one-shot session to a fully embedded program of IL over the course of several semesters in a business strategy capstone course. As the collaboration progressed, the librarians worked with the primary course instructor to revise and grade the final course project, using a jointly developed rubric, as well as a survey. ${ }^{100}$

\section{Standardized Instruments}

- Summative

- $\quad$ Level 2: Learning

Standardized instruments - the final category of assessment - can measure information literacy across institutions. Although most of these are not specific to ILI assessment, they are a significant component of information literacy assessment generally and an important part of the growing body of literature.

The most widely discussed in the literature is the Standardized Assessment of Information Literacy Skills, or SAILS, initially developed by Kent State University and now administered by a private company. This instrument is a multiple-choice test with questions based on the ACRL Standards and Objectives. ${ }^{101}$ SAILS is a programmatic assessment, aimed at establishing internal and external benchmarks, and thus provides aggregate rather than individual scores, making it better suited to institutionwide IL assessment. I found no reports of institutions using SAILS for assessment of specific instruction programs, suggesting that it is generally not used in this context. Although comparison of results across institutions is done, its usefulness has been questioned due to a lack of standardized sampling and grouping procedures. ${ }^{102}$

The Information Literacy Test (ILT), developed at James Madison University, is a similar web-based, standardized test of information literacy designed for use across institutions. ${ }^{103}$ Like SAILS, the ILT is based on the ACRL Standards, specifically numbers 1, 2, 3, and 5 . The ILT measures both lower order and higher order concepts. The instrument has been pilot tested and subjected to measures of both content and construct validity; a standard-setting workshop was used to define benchmarks for "proficient," "below proficient," and "advanced" performance. Although it is intended as a standard instrument usable at any institution, local reliability and validity testing are recommended prior to implementation. ${ }^{104}$ While this recommendation is very useful, it is likely also a reason that reported use of instruments such as ILT and SAILS, especially in stand-alone information literacy instruction programs, is almost nonexistent.

The Educational Testing Service (ETS) has also developed a large-scale, standardized, Internet-based assessment of information and communication technology (ICT) literacy, called iSkills. ${ }^{105}$ ETS created a consortium of seven institutions to assist in the development and testing of the instrument, which contains questions that focus on technology and are based on the ACRL Standards. The instrument, designed to simulate real-life information and technology demands, uses interactive performance-based tasks and has built-in redirection if students get off task or appear to be stuck. Two levels of difficulty are available, and an automated scoring system provides test-takers with their individual scores and institutions with aggregate performance data. Purdue University has implemented iSkills in a pre-/post-test format to assist in the development and assessment of a fully integrated curriculumwide ICT literacy initiative. ${ }^{106}$ 
This review, however, uncovered no case reports of iSkills being used in smaller-scale or stand-alone IL instruction initiatives, suggesting that, like SAILS and ILT, it is best suited to institution-level assessment.

Finally, the Information Literacy Assessment and Advocacy Pilot (ILAAP) instrument is being developed by a group of academic libraries in Alberta, Canada, with the goal of providing a simple and low-cost, but still robust, standardized tool with the scope and flexibility to be used for ILI assessment in different institutions. ${ }^{107}$ The authors assert that existing standardized tools are too costly, time-consuming, and inflexible and lack relevance to local populations. ${ }^{108}$ Like most existing tools, the ILAAP instrument is a multiple-choice test with questions based on ACRL Standards 1, 2, 3, and 5 but, unlike the others, purposefully focuses on lower-order skills appropriate for first- and second-year students in one-shot instruction sessions. The test is customizable in that a small number of cognitive items relevant to the particular instruction session are selected from a pool of possible questions, while the same demographic and affective questions are used each time. The authors report that the initial pilot sample was too small to be generalizable and that validity and reliability testing on the questions is not yet complete, but development is ongoing and they hope to include additional Alberta institutions in later rounds of piloting. ${ }^{109}$

Like other assessment methods, standardized instruments have their own set of strengths and weaknesses. ${ }^{110}$ The strengths of standardized instruments are: do not require local development; use a variety of formats and scenarios; are often more authentic than locally developed tests; are considered valid; useful for establishing a campuswide baseline; useful for starting conversations with stakeholders. Weaknesses of standardized instruments include: high cost of purchase, intimidating to both faculty and students; difficult to recruit students; difficult to interpret data without statistician assistance; difficult to adapt for students with disabilities; lag behind development of research tools and related software; not well suited to assessing at classroom level. ${ }^{111}$

\section{Implications for Practice}

Regardless of the specific method used, the theoretical literature as a whole also points to four general recommendations for quality ILI assessment: 1 ) assessment is an iterative cycle; 2) there is no one-size-fits-all solution; 3) multiple methods should be used; 4) collaboration is encouraged. The body of literature also suggests an overall shift in the type of assessments from lower-level surveys and questionnaires toward more authentic assessment. What follows is an overview of these additional constructs, including analysis of how they have been reflected in practice. It should be noted that omitting something from a published report is not equivalent to omitting it from practice; it is quite possible, for example, that more authors apply the cycle of assessment in practice than write about it in their published articles.

\section{Assessment Is an Iterative Cycle}

Regardless of the assessment methods and tools employed, assessment should be part of an iterative cycle, as suggested by the second goal of assessment: feedback for instructors. This feedback should not just be absorbed but used to revise and improve future instruction in a continuous cycle. There are three distinct cycles discussed in the included literature: ADDIE, IDEA, and ILIAC. Regardless of the particular model used, approaching assessment as an iterative cycle is strongly recommended by many authors reviewed here. ${ }^{112}$

The ADDIE model is not specific to the LIS field and is, in fact, an instructional design model, not an assessment-specific cycle. Since it is employed by librarians, however, I include it in this review. ADDIE was originally designed at Florida State 
University, in the mid-1970s, for use by the U.S. Armed Forces. ${ }^{113}$ The five stages in the ADDIE model are Analysis, Design, Development, Implementation, and Evaluation. According to Reinbold's detailed description of the use of ADDIE at the Weill Cornell Medical College, the process is iterative, and assessment is incorporated in the design and evaluation phases; but it is not the focus of this model. ${ }^{114}$

In 2014, Mullins published an article titled "Good IDEA," presenting a new iterative model for instructional design that is tailored for the integration of ILI into academic courses and can replace the generic ADDIE model in appropriate situations. IDEA is composed of the following four phases: Interview; Design; Embed; Assess. According to Mullins, the interview should be with the course instructor, and the design should support the course goals. She emphasizes that although this instructional design model may appear linear, it should be used iteratively, with assessment results driving subsequent rounds of development. ${ }^{115}$

The Information Literacy Instruction Assessment Cycle (ILIAC), developed by Oakleaf - the only model that is driven entirely by ILI assessment-is designed to provide a framework for instruction librarians to improve learning and teaching and to demonstrate their impact to administrators (the three primary purposes of assessment). ILIAC is grounded in "assessment for learning" theory, which asserts that learning and assessing are inseparable and that students can learn by completing an assessment. ${ }^{116}$ The ILIAC model is composed of seven stages: 1 ) review learning goals; 2) identify learning outcomes; 3) create learning activities; 4) enact learning activities; 5) gather data to check learning; 6) interpret data; 7) enact decisions. Like ADDIE and IDEA, ILIAC is cyclical and iterative, not linear. ${ }^{117}$

The case reports reviewed here do frequently mention the cycle of assessment, though few claim the use of a particular model in practice. Just over 50 percent of the case reports (31 out of 59) make some allusion to the cycle of assessment, though the level of detail provided about its application varies greatly. Specific examples of how the cycle of assessment was applied through at least one round of planning, implementation, evaluation, revision, and reimplementation are given in 24 reports, and an additional two discuss the use of particular frameworks by name. ${ }^{118}$ General allusions to assessment as an iterative process or vague plans to revise future programming based on results are included in an additional five case reports. ${ }^{119}$ It should be noted, however, that articles focusing entirely on application of these cyclic frameworks may well exist and have simply been excluded by the selection criteria applied here.

The cycle of assessment is reported slightly more often in course-embedded ILI than in one-shots. Out of 21 course-embedded programs, 13 (62\%) report using the cycle of assessment, including both Gustavson and Stowe, who discuss the use of specific frameworks (ILIAC and ADDIE). In the more commonly reported one-shot sessions, 18 out of 35 (51\%) discuss the cycle of assessment. Although this frequency is lower than that among course-embedded programs, it still constitutes over half of the programs described. An overall reporting rate of over half suggests that a significant portion of instruction librarians already apply the iterative cycle of assessment, but there is still room for improvement.

\section{There Is No "One-Size-Fits All” Solution}

The review of methods above demonstrates how many options there are for ILI assessment, and the challenge of selecting an appropriate one is frequently discussed in the professional literature. While some methods are generally agreed to be more robust than others, each has its own benefits and challenges. Likewise each instruction program is different and defined by its context, audience, goals, available resources (human, financial, and technological), institutional support, and other factors. In short, each assessment situation is unique, and the method used should be the one that fits 
the best, not the one that is easiest, cheapest, or most popular; the assessment should always match the defined learning outcomes. ${ }^{120}$

Farmer suggests the following considerations when selecting a method: validity, reliability, cost, time, availability, feasibility or practicality, skills, legalities, and (institutional) culture. ${ }^{121}$ Kaplowitz poses a series of questions to help drive the decisionWhat do we need to know? What do stakeholders want to know? How much does it cost? How much time does it take? Does it yield quantitative or qualitative data? Will statistical analysis be required? Will staff training be required? Does it support the larger mission? ${ }^{122}$ Finally, Gilchrist and Zald suggest selecting an assessment method based on what, specifically, you need to know about your learners. ${ }^{123}$ Regardless of the selection process chosen, there should be a deliberate selection process for choosing an ILI assessment method.

That every assessment situation is unique seems obvious, but it is also somewhat difficult to definitively capture in the literature. Most reports, of both one-shot and course-embedded programs, include an overview of the institutions in which they are situated and the courses or programs of which they are a part. Information such as type, size, location, and demographics of the institution are provided across the board, as are details such as course name, level, subject, average number of students enrolled per section, and number of librarians available for instruction. This kind of information certainly suggests that each situation is unique, but it is not often tied directly to choice of assessment method in the practical literature. Most of the reports also include literature reviews that focus on the particular methods they chose, extolling the benefits and supplying examples of successful implementation by others. While this information is useful and situates their reports within the larger body of literature, it does not fully constitute a rationale for selection in their own unique situation.

A few standout reports do make an explicit connection between their particular situations and the assessment methods they chose to use. Hsieh and Holden explain their choice of a combined survey and objective test method based on both time limitations and the notion that lower-order skills are an appropriate place to begin with their freshman student audience. ${ }^{124}$ Likewise, Smale and Regalado explain that the benefits of an objective test outweighed the limitations in the context of the IL program at their institution. ${ }^{125}$ Rimland provides a different rationale for her choice of the survey method: she was primarily interested in studying the effects of ILI on the affective domain of learning. ${ }^{126}$ Several other authors mention selecting their assessment method based on what they wanted to know about their students as a result of the assessment. ${ }^{127}$ Interestingly, in the case of this recommendation, all three of the most robust examples come from reports of one-shot sessions; of those included here, only one reports on a course-embedded ILI program. ${ }^{128}$ Overall, the published reports suggest that this recommendation is not being consistently applied in practice.

\section{Use Multiple Methods}

Because the available options for assessment are many and can provide such varied data, it is generally agreed that the use of multiple methods is advisable whenever possible. The use of multiple methods not only provides a richer and more complete data set, but also acknowledges different learning styles and various levels and domains of learning. ${ }^{129}$ Grassian and Kaplowitz assert that the type of assessment should be driven by the question you want to answer; if you want to answer more than one question, you may need to employ more than one type of assessment (this is grounded in Kirkpatrick's four levels and their associated questions). ${ }^{130}$ Because authentic assessments can be more challenging and time-consuming, Twomey suggests only using them to measure complex concepts and sticking with quicker traditional methods (like objective tests) for 
simpler concepts. ${ }^{131}$ While these authors make specific recommendations for applying this principle in practice, many others simply make a general recommendation for the use of multiple methods to provide a richer picture of student learning outcomes. ${ }^{132}$

In practice, just under half of the reports discuss the use of multiple methods (27 out of 59 , or $46 \%$ overall). There is a striking difference, however, between reports of one-shots and course-embedded programs. The 12 reports of multiple methods used in one-shots (out of 36 total) constitute only 33 percent of the total reports of this type of session, whereas the 13 instances among the 21 course-embedded programs is well over half $(62 \%)$. Time is likely a significant factor in this discrepancy. This assumption is supported by the fact that 49 percent of the one-shot cases report the use of CATs and performance measures, which are integrated into the learning itself and do not require added time at the end of the session to complete. Additionally, both instances of administering objective tests outside the session, using Blackboard, were reported by authors who provided one-shot ILI, further supporting the idea that the limited time allotted to one-shots affects the methods of assessment employed.

Although time is a factor, the fact that some instruction librarians achieve the goal of multiple assessment methods in a single session demonstrates that it is possible and suggests that there is much room for improvement. Even among the course-embedded programs, more than one-quarter report the use of only one method, leaving room for improvement among this group as well.

\section{Collaborate Whenever Possible}

Several of the assessment methods reviewed in the last section require a high degree of faculty collaboration, but such collaboration should not be limited to the use of those methods. Information literacy is being increasingly integrated into the higher education curriculum, and librarians are called upon more often to prove their contribution to student learning in this area. Effective collaboration with faculty can help to align IL instructional goals and outcomes with those of the academic curriculum, which can, in turn, foster partnerships and result in more course-embedded and fewer stand-alone one-shot information literacy instruction programs. ${ }^{133}$ Several authors also recommend sharing assessment results with decision-makers, including department faculty, whenever possible to garner support and foster increased collaboration in information literacy initiatives; even negative results can demonstrate the need for greater support of IL initiatives. ${ }^{134}$

It comes as no surprise then that collaboration is mentioned, at least in passing, in 61 percent ( 36 of 59) of the case reports overall. This area also demonstrates one of the greatest discrepancies between one-shots and course-embedded sessions: collaboration is a topic of discussion in 85 percent (18 of 21) of the case reports of courseembedded ILI; in sharp contrast, only 47 percent (17 of 36) of the reports of one-shot sessions include it. Two-thirds of the reports that discuss collaboration ( 24 total) can be classed in a lower tier that includes general discussion of its importance to IL, getting class-time for one-shots, the assignment of course points to IL activities, and eliciting faculty feedback. ${ }^{135}$

The remaining one-third of the reports of successful collaboration constitute an exceptional level of collaboration and, in most cases, full integration into a particular academic course, often at the upper level of the curriculum. These include librarian input and collaboration with academic faculty on course outcomes/design, project design, grading, and the contribution of content to custom textbooks. Only one of these cases is reported among the one-shots, in which the authors successfully collaborated with faculty in a general course for academically at-risk freshmen and were given two of the twenty customizable textbook pages to cover library content. ${ }^{136}$ The remaining 
cases of exceptional collaboration are all course-embedded programs, mostly in direct connection with one particular course. Science courses are especially prevalent among these cases, with full collaboration reported in five cases including biology, chemistry, and honors science classes. ${ }^{137}$ Two such collaborations occurred in business capstone courses, ${ }^{138}$ and one each in art, math, and social science. ${ }^{139}$ The final outstanding example of collaboration involved the use of a rubric to compare the final papers of students enrolled in different classes with varying levels of librarian faculty collaboration. ${ }^{140}$ The mantra here is that collaboration begets collaboration; many of the major collaborations started small and grew exponentially. While many ILI programs have a long way to go, it is clear that collaboration is at least on the radar, so to speak, in the majority of reports.

\section{A Shifting Trend?}

My review of the theoretical and background literature on ILI assessment also revealed something of a discrepancy regarding a possible shift away from the use of surveys and toward more authentic assessment techniques. Sobel and Wolf, and Oakleaf, both writing in 2011, alleged that such a shift was already underway. ${ }^{141}$ But, three years earlier, Oakleaf had reported very limited use of rubrics according to a review of the literature; and, in their 2012 review, Schilling and Applegate reported that affective measures were more common than cognitive. ${ }^{142}$ So there appears to be a disagreement within the theoretical regarding what is actually being done in practice.

Analysis of the methods used in the reports included here (from 2006 to 2016) suggests that a shift may be occurring but that it is more complex than a one-to-one exchange, in which the use of authentic assessment increases as the use of surveys decreases. Rather, it seems that the use of authentic assessment and multiple methods is increasing over time, while the percentage use of surveys has fluctuated but not diminished overall. In fact, surveys were used in 28.6 percent of the reports published in 2006 and 28.5 percent of those published in 2016, demonstrating almost no net change over the course of ten years. Figures 1 and 2 provide graphic representations of this complex trend. It should be noted that the two claims of progressively diminishing use of surveys, by Oakleaf and by Sobel and Wolf, were both published in 2011, when their use had in fact been on the decline and almost reached its nadir in published reports, prior to bouncing back in subsequent years.

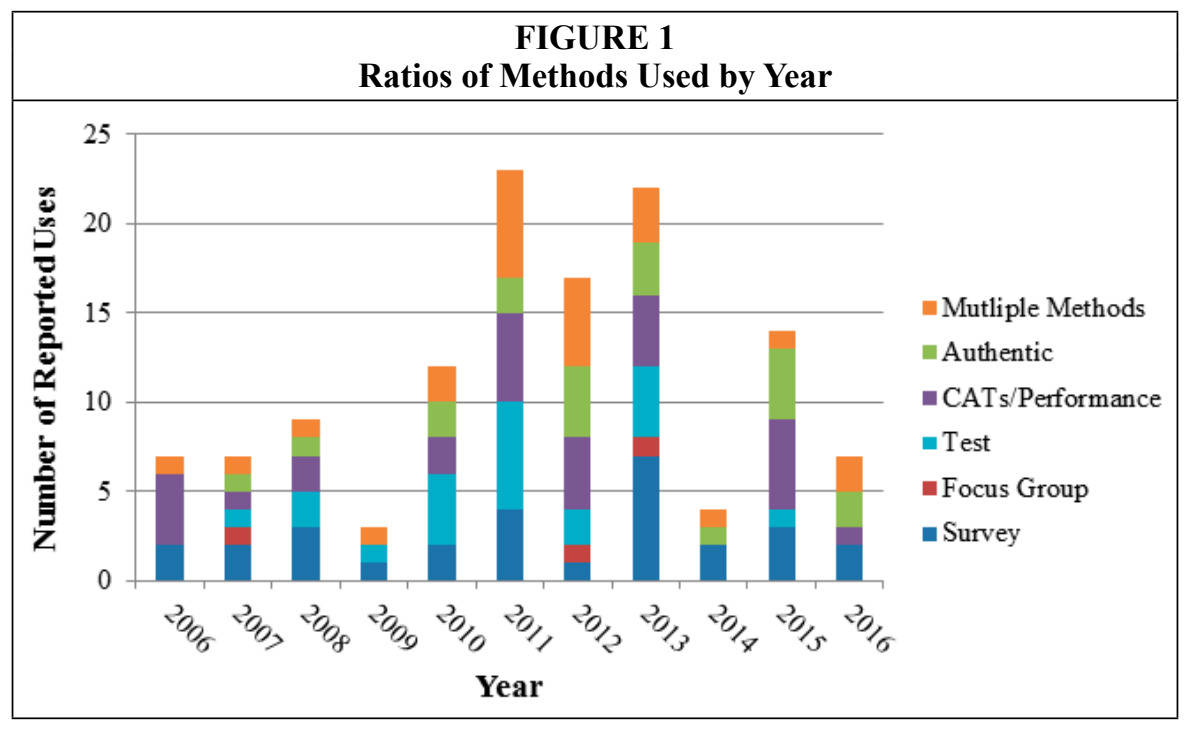




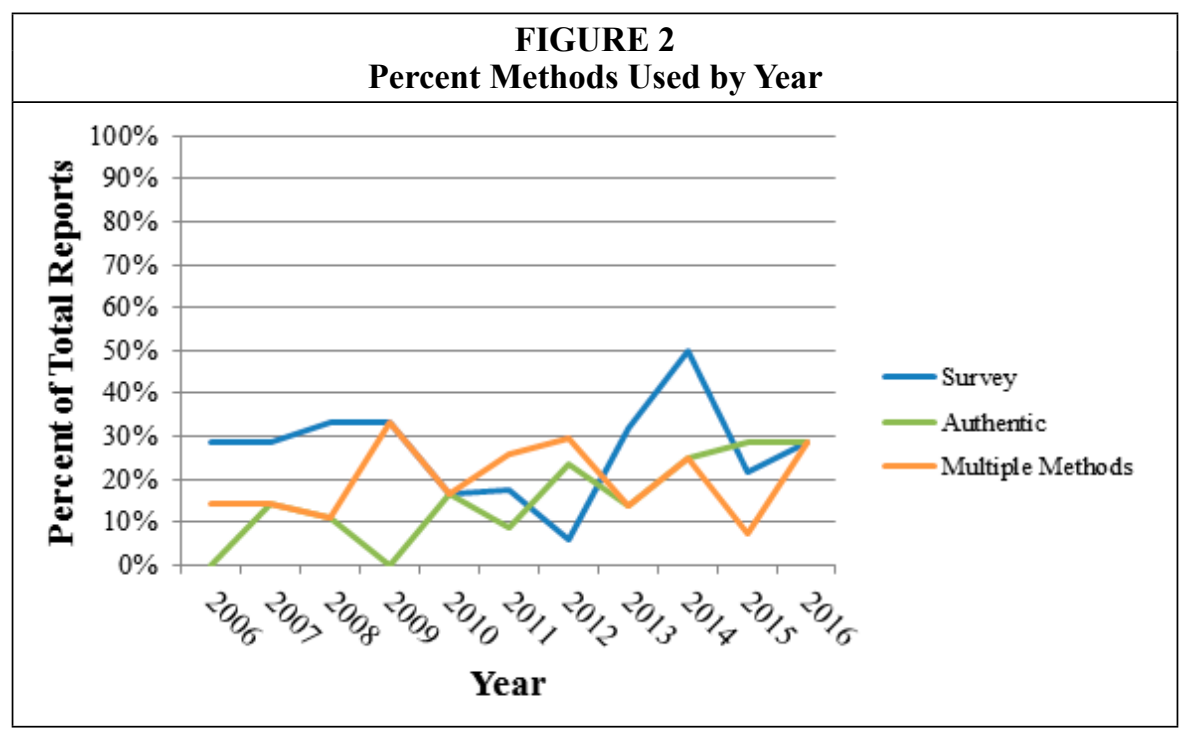

Narrative data from the case reports also suggests that, while some programs have changed the methods they use, it is not as simple as replacing surveys with authentic assessments. Four authors do report changing from the use of objective tests and/or surveys to performance-based or authentic assessment methods. ${ }^{143}$ But that is not the whole story; another two discuss the change from strictly reaction-based "happiness scales" to surveys that include measures of confidence, self-report of behavior, and other more authentic assessment measures. ${ }^{144}$ Taken together, the numeric and narrative data support a more complex shift in ILI assessment trends, in which authentic assessment and multiple methods are becoming more common and surveys are becoming more robust and are paired with other methods, rather than being phased out entirely.

Another way to look at the trend that emerges from the practical literature is that the overall assessment toolkits of many instruction librarians are shifting up the four levels of assessment defined by Kirkpatrick: Level 1 assessments, such as surveys, are being redesigned and paired with Level 3 assessments, such as performance measures and authentic assessment. In some cases, Level 2 assessments, including objective tests, are being replaced by Level 3 assessments including CATs/performance measures and authentic assessments. These changes are producing an overall effect of more Level 3 assessment occurring overall, but not entirely subsuming Level 1 and 2 methods.

\section{Limitations}

This review includes items indexed in two major Library and Information Science databases; Library, Information Science, \& Technology Abstracts (LISTA); and Library Literature and may have missed relevant items indexed elsewhere. The use of bibliographic mining of the items retrieved from the databases mitigates this effect to some extent, but some relevant items were likely excluded. Items published in non-LIS journals, such as among general educational literature, were excluded due to limitations in scope, despite their potential relevance to the topic. The exclusion of items published outside the United States and Canada also limits the applicability of this study to other geographic areas, particularly Europe, Australia, and New Zealand, each of which has its own extensive body of literature on the topic. The scope of this review is limited to face-to-face instruction delivered to undergraduates at traditional four-year colleges 
and universities. A number of items covering graduate/professional and community college populations, as well as assessment of online ILI and stand-alone IL courses were excluded and warrant separate consideration in future research.

\section{Discussion}

This review set out to answer three questions about ILI assessment of undergraduate students in traditional four-year colleges and universities in North America: What do we know about assessment methods and what general recommendations exist? What assessment methods are academic librarians actually using? How does professional practice compare to existing recommendations?

A detailed review of the theoretical literature provides an answer to question 1 . This portion of the review identified two frameworks for assessment methods, seven methodological categories, four general recommendations for practice, and one reported trend in the use of assessment methods. The existence of such a broad and well-faceted theoretical foundation suggests that the LIS profession as a whole has fully acknowledged that the provision of demonstrable educational outcomes in higher education through effective IL instruction and assessment is necessary. Striving to develop a solid theoretical foundation for ILI assessment suggests that as a professional whole we are committed fully to integrating this expanding role as educators into our profession and to developing a consensus on how it should operate in the ILI context.

Perhaps the greatest challenge with the theoretical basis for ILI assessment as it currently exists, however, is this very breadth and variation. For the purposes of this review, I had to select from among many more frameworks and categorizations of assessment than are specifically discussed here, many of which have overlapping dimensions. Since many theorists simultaneously develop their own schemas, such variation is not altogether surprising and, like most of the specific constructs described above, has its own benefits and challenges. Being able to approach ILI assessment from many angles, each with its own framework, allows for a narrower focus in selection depending on the particular need. But it can also create confusion and make it more difficult for beginning professionals to fully grasp the larger concept of assessment. This may create a particular difficulty in light of the tendency for on-the-job learning and self-teaching of assessment theory and practice that was identified by Sobel and Sugimoto in their survey of instruction librarians. ${ }^{145}$

A review of the practical literature addresses question 2. That 59 reports of practice meeting the criteria for this review have been published in the last ten years alone supports the idea that academic librarians are embracing their role as educators on campus. When considered alongside Sobel and Sugimoto's finding that only a small portion of instruction librarians publish their assessment practices externally, this volume of published reports supports the notion that IL assessment is being implemented, one way or another, on a very large scale. ${ }^{146}$

My findings do reflect a change from the results of Schilling and Applegate's review, which included reports published from 2007 to 2012 and found affective measures to be the most common. In the reports reviewed here, CATs/performance measures are the most common type of assessment, which is in line with the results of Sobel and Sugimoto's 2012 survey. ${ }^{147}$ The data also suggest a more complex shift in IL assessment than originally reported in 2011 by Sobel and Wolf and by Oakleaf. ${ }^{148}$ While it once may have seemed that surveys were being replaced by more authentic assessment methods, the data suggest that a more nuanced change in methods has been underway over the last ten years. Surveys are still in use but are becoming more robust and are being paired with higher-level assessments; overall, librarians' assessment toolkits seem to be moving up Kirkpatrick's four levels of assessment. That such a shift is occurring also 
suggests that IL assessment is becoming more sophisticated as it continues to develop into an integral component of academic librarianship.

A somewhat unexpected finding is the lack of consistent terminology within the practical literature on ILI assessment. The definitions employed in this review are generally agreed upon and explicitly delineated in the theoretical and background literature but are not carefully applied in the case reports of practice. This lack of consistent terminology among practitioners is likely due, at least in part, to their lack of formal preparation for instruction and assessment activities prior to performing them on the job. Sobel and Sugimoto's survey found that 81 percent of respondents reported learning how to perform assessments on the job and that less than 20 percent reported learning assessment techniques in their MLS program. ${ }^{149}$ Being required to assess, but not being equipped to do so is, unfortunately, common among academic instruction librarians. ${ }^{150}$ Although the practical aspects of assessment could feasibly be mastered in adequate on-the-job training and practice, a lack of adequate theoretical preparation likely contributes to confusion about both the methods and the dimensions of assessment. The lack of a consistent and discrete vocabulary makes the development of a cohesive body of literature a challenge, which in turn detracts from the ability to present a strong case to stakeholders and administrators for librarians as IL educators.

A review of the general recommendations in the literature addresses question 3. Instruction librarians are performing fairly well on recommendation 1-assessment is an iterative cycle-with an overall reporting rate of about half. Application of the principle that every assessment situation is unique (recommendation 2) was difficult to glean from the literature. Many authors provide detailed descriptions of their institutions and complete literature reviews on their chosen method(s), but few make an explicit connection between the two that explains how their unique situation led to their selection of a method. Recommendations 3 and 4 -use multiple methods and collaborate whenever you can-saw the greatest discrepancies between course-embedded programs and one-shot sessions. Librarians conducting course-embedded programs are excelling in these areas overall, and many of those teaching one-shots appear to know the recommendations and to try their best to apply them under local constraints. My review of the practical literature did not uncover any additional major constructs or principles that the theoretical literature does not address. Although the derivative relationship between the theoretical and practical literature can be viewed, and certainly functions, in both directions, that the major constructs generally match up suggests that the theoretical foundation for ILI assessment is strong and well-rounded and that practitioners are aware of its major components.

Considering everything together, it appears that ILI assessment has a solid theoretical foundation and that many instruction librarians are finding success in the application of principles to practice. The biggest gaps that emerge from this review are in the areas of training and reporting. Few instruction librarians report learning how to assess in their MLS programs, and, according to Sobel and Sugimoto, even fewer publish their results in professional journals. ${ }^{151}$ Among those who do publish their results externally, there is a lack of consistent terminology, which detracts from an already limited body of literature. The good news is that, even with such a low reported publishing rate, the literature on this topic is vast, meaning that the number of librarians actually involved in assessment is huge. This review also found several reports of outstanding collaboration, full course integration, and the use of best practices in assessment, demonstrating that this can be, and is in fact being, accomplished. 


\section{Conclusion}

Through the analysis and synthesis of 102 discrete published artifacts, this review sought to answer three closely linked questions about librarian-led assessment of library and information literacy instruction among undergraduate students at fouryear colleges and universities in North America. What emerges is a broad theoretical foundation on which instruction librarians are working hard to successfully build. As is to be expected, some are faring better than others, and the reports run the gamut from a single 50-minute session assessed with a simple paper survey, to fully courseintegrated IL programs with very robust assessments to match, and everything in between. Perhaps the greatest strength overall is an acknowledgement of the theoretical foundation and seminal documents, in particular the ACRL Standards, in almost every item reviewed. This suggests that, although not every instruction librarian is currently in a situation that allows for best practice implementation, they are aware of it as a goal and are doing their best with the resources at their disposal.

The scope of this review was relatively narrow, covering only assessment of traditional in-person instruction among the undergraduate population in North America. Further research is needed that expands the scope in terms of format, target population, and geographical area. An additional 24 items were identified that discussed assessment of ILI delivered online and had to be eliminated due to constraints of time and scope. As online learning becomes increasingly common, this is an area in which research regarding IL instruction and assessment could prove very fruitful. Assessment of stand-alone for-credit IL courses was also eliminated from this review due to the vastly different opportunities it affords when compared to one-shots and courseembedded series. This is another area for further research.

Although this review is limited in breadth, the depth of information and analysis provided was not found in any previous reviews on the topic of ILI assessment. The comparison of practice to theory paints a picture of where academic instruction librarians in North America currently stand as a professional whole. Knowing where we are now and where we ideally want to and should be provides a direction in which to go as we move forward, as well as a few specific goals to shoot for along the way. 


\section{APPENDIX A. Items Reviewed by Category}

The following tables include only the 102 items included in the formal review. Additional references were used for background information and appear only in the notes.

\begin{tabular}{|c|c|c|}
\hline \multicolumn{3}{|c|}{ Reviewed Items: Theory } \\
\hline Author(s) & Year & Title \\
\hline Beile & 2007 & $\begin{array}{l}\text { Assessing an Institution-Wide Information Fluency } \\
\text { Program: Commitment, Plan, and Purposes }\end{array}$ \\
\hline $\begin{array}{l}\text { Belanger, Zou, Rushing } \\
\text { Mills, Holmes, and Oakleaf }\end{array}$ & 2015 & $\begin{array}{l}\text { Project RAILS: Lessons Learned about Rubric As- } \\
\text { sessment of Information Literacy Skills }\end{array}$ \\
\hline Blanchett, Webb, and Powis & 2012 & $\begin{array}{l}\text { A Guide to Teaching Information Literacy: } 101 \\
\text { Practical Tips }\end{array}$ \\
\hline Brooks & 2013 & $\begin{array}{l}\text { Maximizing One-Shot Impact: Using Pretest Re- } \\
\text { sponses in the Information Literacy Classroom }\end{array}$ \\
\hline Broussard & 2014 & $\begin{array}{l}\text { Using Games to Make Formative Assessment Fun } \\
\text { in the Academic Library }\end{array}$ \\
\hline $\begin{array}{l}\text { Broussard, Hickoff-Cresko, } \\
\text { and Oberlin }\end{array}$ & 2014 & $\begin{array}{l}\text { Snapshots of Reality: A Practical Guide to Forma- } \\
\text { tive Assessment in Library Instruction }\end{array}$ \\
\hline Cahoy and Schroeder & 2012 & $\begin{array}{l}\text { Embedding Affective Learning Outcomes in Li- } \\
\text { brary Instruction }\end{array}$ \\
\hline $\begin{array}{l}\text { Cameron, Wise, and } \\
\text { Lottridge }\end{array}$ & 2007 & $\begin{array}{l}\text { The Development and Validation of the Informa- } \\
\text { tion Literacy Test }\end{array}$ \\
\hline Farmer & 2011 & $\begin{array}{l}\text { Instructional Design for Librarians and Informa- } \\
\text { tion Professionals }\end{array}$ \\
\hline Fluk & 2015 & $\begin{array}{l}\text { Foregrounding the Research Log in Information } \\
\text { Literacy Instruction }\end{array}$ \\
\hline Gilchrist and Zald & 2008 & Instruction \& Program Design through Assessment \\
\hline $\begin{array}{l}\text { Goebel, Knoch, Thomson, } \\
\text { Willson, and Sharun }\end{array}$ & 2013 & $\begin{array}{l}\text { Making Assessment Less Scary: Academic Librar- } \\
\text { ies Collaborate on an Information Literacy Assess- } \\
\text { ment Model }\end{array}$ \\
\hline Grassian and Kaplowitz & 2009 & $\begin{array}{l}\text { Information Literacy Instruction: Theory and } \\
\text { Practice }\end{array}$ \\
\hline Grassian and Kaplowitz & 2010 & Information Literacy Instruction \\
\hline Holmes and Oakleaf & 2013 & $\begin{array}{l}\text { The Official (and Unofficial) Rules for Norming } \\
\text { Rubrics Successfully }\end{array}$ \\
\hline Kaplowitz & 2014 & $\begin{array}{l}\text { Designing Information Literacy Instruction: The } \\
\text { Teaching Tripod Approach }\end{array}$ \\
\hline Katz & 2007 & $\begin{array}{l}\text { Testing Information Literacy in Digital Environ- } \\
\text { ments: ETS's iSkills Assessment }\end{array}$ \\
\hline $\begin{array}{l}\text { Lym, Grossman, Yannotta, } \\
\text { and Talih }\end{array}$ & 2009 & $\begin{array}{l}\text { Assessing the Assessment: How Institutions Ad- } \\
\text { ministered, Interpreted, and Used SAILS }\end{array}$ \\
\hline McCulley & 2009 & $\begin{array}{l}\text { Mixing and Matching: Assessing Information } \\
\text { Literacy }\end{array}$ \\
\hline Mullins & 2014 & $\begin{array}{l}\text { Good IDEA: Instructional Design Model for Inte- } \\
\text { grating Information Literacy }\end{array}$ \\
\hline
\end{tabular}


Outcomes Assessment in Undergraduate Information Literacy Instruction 465

\begin{tabular}{|c|c|c|}
\hline Murtha, Stec, and Wilt & 2006 & $\begin{array}{l}\text { Using Assessment as a Tool to Improve Learning: } \\
\text { An IFLA Workshop }\end{array}$ \\
\hline Oakleaf & 2007 & $\begin{array}{l}\text { Using Rubrics to Collect Evidence for Decision- } \\
\text { Making: What Do Librarians Need to Learn? }\end{array}$ \\
\hline Oakleaf & 2008 & $\begin{array}{l}\text { Dangers and Opportunities: A Conceptual Map of } \\
\text { Information Literacy Assessment Approaches }\end{array}$ \\
\hline Oakleaf & 2009 & $\begin{array}{l}\text { The Information Literacy Instruction Assessment } \\
\text { Cycle: A Guide for Increasing Student Learning } \\
\text { and Improving Librarian Instructional Skills }\end{array}$ \\
\hline Oakleaf & 2009 & $\begin{array}{l}\text { Using Rubrics to Assess Information Literacy: An } \\
\text { Examination of Methodology and Interrater Reli- } \\
\text { ability }\end{array}$ \\
\hline Oakleaf & 2009 & $\begin{array}{l}\text { Writing Information Literacy Assessment Plans: A } \\
\text { Guide to Best Practice }\end{array}$ \\
\hline Oakleaf & 2011 & $\begin{array}{l}\text { Are They Learning? Are We? Learning Outcomes } \\
\text { and the Academic Library }\end{array}$ \\
\hline Oakleaf & 2014 & $\begin{array}{l}\text { A Roadmap for Assessing Student Learning Using } \\
\text { the New Framework for Information Literacy for } \\
\text { Higher Education }\end{array}$ \\
\hline Oakleaf and Kaske & 2009 & $\begin{array}{l}\text { Guiding Questions for Assessing Information } \\
\text { Literacy in Higher Education }\end{array}$ \\
\hline $\begin{array}{l}\text { Oakleaf, Hoover, Woodard, } \\
\text { Corbin, Hensley, Wakimoto, } \\
\text { Hollister, Gilchrist, Millet, } \\
\text { and Iannuzzi }\end{array}$ & 2012 & $\begin{array}{l}\text { Notes from the Field: } 10 \text { Short Lessons on One- } \\
\text { Shot Instruction }\end{array}$ \\
\hline Oakleaf, Millet, and Kraus & 2011 & $\begin{array}{l}\text { All Together Now: Getting Faculty, Administra- } \\
\text { tors, and Staff Engaged in Information Literacy } \\
\text { Assessment }\end{array}$ \\
\hline $\begin{array}{l}\text { Radcliff, Jensen, Salem Jr., } \\
\text { Burhanna, and Gedeon }\end{array}$ & 2007 & $\begin{array}{l}\text { A Practical Guide to Information Literacy Assess- } \\
\text { ment for Academic Librarians }\end{array}$ \\
\hline Reinbold & 2013 & $\begin{array}{l}\text { Using the ADDIE Model in Designing Library } \\
\text { Instruction }\end{array}$ \\
\hline Rumble and Noe & 2009 & $\begin{array}{l}\text { Project SAILS: Launching Information Literacy } \\
\text { Assessment across University Waters }\end{array}$ \\
\hline Schilling and Applegate & 2012 & $\begin{array}{l}\text { Best Methods for Evaluating Educational Impact: } \\
\text { A Comparison of the Efficacy of Commonly Used } \\
\text { Measures of Library Instruction }\end{array}$ \\
\hline Seeber & 2013 & $\begin{array}{l}\text { Using Assessment Results to Reinforce Campus } \\
\text { Partnerships }\end{array}$ \\
\hline $\begin{array}{l}\text { Sharun, Thompson, Goebel, } \\
\text { and Knoch }\end{array}$ & 2014 & $\begin{array}{l}\text { Institutions Collaborating on an Information Lit- } \\
\text { eracy Assessment Tool }\end{array}$ \\
\hline Sobel and Sugimoto & 2012 & $\begin{array}{l}\text { Assessment of Learning during Library Instruction: } \\
\text { Practices, Prevalence, and Preparation }\end{array}$ \\
\hline Sobel and Wolf & 2011 & $\begin{array}{l}\text { Updating your Tool Belt: Redesigning Assessments } \\
\text { of Learning in the Library }\end{array}$ \\
\hline
\end{tabular}




\begin{tabular}{|l|c|l|}
\hline $\begin{array}{l}\text { Somerville, Smith, and } \\
\text { Macklin }\end{array}$ & 2008 & The ETS iSkills Assessment: A Digital Age Tool \\
\hline $\begin{array}{l}\text { Tancheva, Andrews, and } \\
\text { Steinhart }\end{array}$ & 2007 & $\begin{array}{l}\text { Library Instruction Assessment in Academic } \\
\text { Libraries }\end{array}$ \\
\hline Twomey & 2015 & $\begin{array}{l}\text { Authentic Assessments: Praxis for the Distance } \\
\text { Librarian }\end{array}$ \\
\hline Veldof & 2006 & $\begin{array}{l}\text { Creating the One-Shot Library Workshop: A Step- } \\
\text { by-Step Guide }\end{array}$ \\
\hline Whitlock and Nanavati & 2012 & $\begin{array}{l}\text { A Systematic Approach to Performative and Au- } \\
\text { thentic Assessment }\end{array}$ \\
\hline
\end{tabular}

\begin{tabular}{|c|c|c|}
\hline \multicolumn{3}{|c|}{ Reviewed Items: Practice } \\
\hline Author(s) & $\begin{array}{l}\text { Pub. } \\
\text { Year }\end{array}$ & Title \\
\hline Angell & 2015 & $\begin{array}{l}\text { The Application of Reliability and Validity Measures } \\
\text { to Assess the Effectiveness of an Undergraduate } \\
\text { Citation Rubric }\end{array}$ \\
\hline Angell and Boss & 2016 & $\begin{array}{l}\text { Adapting the Amazing Library Race: Using Problem- } \\
\text { Based Learning in Library Orientations }\end{array}$ \\
\hline $\begin{array}{l}\text { Belanger, Bliquez, and } \\
\text { Mondal }\end{array}$ & 2012 & $\begin{array}{l}\text { Developing a Collaborative Faculty-Librarian } \\
\text { Information Literacy Assessment Project }\end{array}$ \\
\hline $\begin{array}{l}\text { Bluemle, Makula, and } \\
\text { Rogal }\end{array}$ & 2013 & $\begin{array}{l}\text { Learning by Doing: Performance Assessment of } \\
\text { Information Literacy across the First-Year Curriculum }\end{array}$ \\
\hline $\begin{array}{l}\text { Booth, Lowe, Tagge, } \\
\text { and Stone }\end{array}$ & 2015 & $\begin{array}{l}\text { Degrees in Impact: Analyzing the Effects of } \\
\text { Progressive Librarian Course Collaborations on } \\
\text { Student Performance }\end{array}$ \\
\hline $\begin{array}{l}\text { Boss, Angell, and } \\
\text { Tewell }\end{array}$ & 2015 & $\begin{array}{l}\text { The Amazing Library Race: Tracking Student } \\
\text { Engagement and Learning Comprehension in Library } \\
\text { Orientations }\end{array}$ \\
\hline Bowles-Terry & 2012 & $\begin{array}{l}\text { Library Instruction and Academic Success: A Mixed- } \\
\text { Methods Assessment of a Library Instruction Program }\end{array}$ \\
\hline Broussard & 2010 & $\begin{array}{l}\text { Secret Agents in the Library: Integrating Virtual and } \\
\text { Physical Games in a Small Academic Library }\end{array}$ \\
\hline $\begin{array}{l}\text { Brown and Kingsley- } \\
\text { Wilson }\end{array}$ & 2010 & $\begin{array}{l}\text { Assessing Organically: Turning an Assignment into an } \\
\text { Assessment }\end{array}$ \\
\hline Bryan and Karshmer & 2013 & $\begin{array}{l}\text { Assessment in the One-Shot session: Using Pre- } \\
\text { and Post-Tests to Measure Innovative Instructional } \\
\text { Strategies among First Year Students }\end{array}$ \\
\hline $\begin{array}{l}\text { Byerly, Downey and } \\
\text { Ramin }\end{array}$ & 2006 & $\begin{array}{l}\text { Footholds and Foundations: Setting Freshman on the } \\
\text { Path of Lifelong Learning }\end{array}$ \\
\hline Carter & 2013 & $\begin{array}{l}\text { Use What you Have: Authentic Assessment of In- } \\
\text { Class Activities }\end{array}$ \\
\hline Choinski and Emanuel & 2006 & $\begin{array}{l}\text { The One-Minute Paper and the One-Hour Class: } \\
\text { Outcomes Assessment for One-Shot Library } \\
\text { Instruction }\end{array}$ \\
\hline
\end{tabular}


Outcomes Assessment in Undergraduate Information Literacy Instruction 467

\begin{tabular}{|c|c|c|}
\hline $\begin{array}{l}\text { Coulter, Clarke, and } \\
\text { Scamman }\end{array}$ & 2007 & $\begin{array}{l}\text { Course Grade as a Measure of the Effectiveness of } \\
\text { One-Shot Information Literacy Instruction }\end{array}$ \\
\hline Cunningham & 2006 & $\begin{array}{l}\text { Using 'Ready-to-Go' Assessment Tools to Create } \\
\text { a Year Long Assessment Portfolio and Improve } \\
\text { Instruction }\end{array}$ \\
\hline $\begin{array}{l}\text { Dearing, Alexander, and } \\
\text { Parente }\end{array}$ & 2006 & $\begin{array}{l}\text { Using Student Response System to Obtain Real Time } \\
\text { Assessment of Bibliographic Instruction Sessions }\end{array}$ \\
\hline $\begin{array}{l}\text { Dennis, Murphey, and } \\
\text { Rogers }\end{array}$ & 2011 & $\begin{array}{l}\text { Assessing Information Literacy Comprehension in } \\
\text { First-Year Students }\end{array}$ \\
\hline Fain & 2011 & $\begin{array}{l}\text { Assessing Information Literacy Skills Development in } \\
\text { First Year Students: A Multi-Year Study }\end{array}$ \\
\hline $\begin{array}{l}\text { Ferrer-Vinent and } \\
\text { Carello }\end{array}$ & 2008 & $\begin{array}{l}\text { Embedded Library Instruction in a First Year-Biology } \\
\text { Laboratory Course }\end{array}$ \\
\hline $\begin{array}{l}\text { Ferrer-Vinent and } \\
\text { Carello }\end{array}$ & 2011 & $\begin{array}{l}\text { The Lasting Value of an Embedded, First-Year, } \\
\text { Biology Library Instruction Program }\end{array}$ \\
\hline Fuselier and Nelson & 2011 & $\begin{array}{l}\text { A Test of the Efficacy of an Information Literacy } \\
\text { Lesson in an Introductory Biology Laboratory Course } \\
\text { with a Strong Science-Writing Component }\end{array}$ \\
\hline Gilbert & 2009 & $\begin{array}{l}\text { Using Assessment Data to Investigate Library } \\
\text { Instruction for First Year Students }\end{array}$ \\
\hline Gilstrap and Dupree & 2008 & $\begin{array}{l}\text { Assessing Learning, Critical Reflection, and Quality } \\
\text { Educational Outcomes: The Critical Incident } \\
\text { Questionnaire }\end{array}$ \\
\hline Gratz and Olson & 2014 & $\begin{array}{l}\text { Evolution of a Culture of Assessment: Developing } \\
\text { a Mixed-Methods Approach for Evaluating Library } \\
\text { Instruction }\end{array}$ \\
\hline Greer & 2015 & $\begin{array}{l}\text { Connecting Inspiration with Information: Studio Art } \\
\text { Students and Information Literacy Instruction }\end{array}$ \\
\hline $\begin{array}{l}\text { Gross, Chang, and } \\
\text { Dineen }\end{array}$ & 2016 & $\begin{array}{l}\text { Strengthening Information Literacy in a Writing- } \\
\text { designated Course in the Mathematics Major }\end{array}$ \\
\hline Gustavson & 2012 & $\begin{array}{l}\text { Using ILIAC to Systematically Plan and Implement a } \\
\text { Library Information Literacy Assessment Program for } \\
\text { Freshman Classes }\end{array}$ \\
\hline Helms and Whitesell & 2013 & $\begin{array}{l}\text { Transitioning to the Embedded Librarian Model and } \\
\text { Improving the Senior Capstone Business Strategy } \\
\text { Course }\end{array}$ \\
\hline $\begin{array}{l}\text { Hottinger, Zagami- } \\
\text { Lopez, and Bryndzia }\end{array}$ & 2015 & $\begin{array}{l}\text { FYI for FYE: } 20 \text { Minute Instruction for Library } \\
\text { Orientation }\end{array}$ \\
\hline Houlson & 2007 & $\begin{array}{l}\text { Getting Results from One-Shot Instruction: A } \\
\text { Workshop for First-Year Students }\end{array}$ \\
\hline Hsieh and Holden & 2010 & $\begin{array}{l}\text { The Effectiveness of a University's Single-Session } \\
\text { Information Literacy Instruction }\end{array}$ \\
\hline $\begin{array}{l}\text { Johnson, Anelli, } \\
\text { Galbraith, and Green }\end{array}$ & 2011 & $\begin{array}{l}\text { Information Literacy Instruction and Assessment in an } \\
\text { Honors College Science Fundamentals Course }\end{array}$ \\
\hline
\end{tabular}




\begin{tabular}{|c|c|c|}
\hline Karshmer and Bryan & 2011 & $\begin{array}{l}\text { Building a First-Year Information Literacy } \\
\text { Experience: Integrating Best Practices in Education } \\
\text { and ACRL IL Competency Standards for Higher } \\
\text { Education }\end{array}$ \\
\hline Lacy and Chen & 2013 & $\begin{array}{l}\text { Rethinking Library Instruction: Using Learning- } \\
\text { Outcome-Based Design to Teach Online Search } \\
\text { Strategies }\end{array}$ \\
\hline $\begin{array}{l}\text { Lundstrom, Diekema, } \\
\text { Leary, Haderlie, and } \\
\text { Holliday }\end{array}$ & 2015 & $\begin{array}{l}\text { Teaching and Learning Information Synthesis: An } \\
\text { Intervention and Rubric Based Assessment }\end{array}$ \\
\hline $\begin{array}{l}\text { McClurg, Powelson, } \\
\text { Lang, Aghajafari, and } \\
\text { Edworthy }\end{array}$ & 2015 & $\begin{array}{l}\text { Evaluating Effectiveness of Small Group Information } \\
\text { Literacy Instruction for Undergraduate Medical } \\
\text { Education Students Using a Pre- and Post-Survey } \\
\text { Study Design }\end{array}$ \\
\hline Moreton and Conklin & 2015 & $\begin{array}{l}\text { Closing the Loop on Nursing Library Instruction: } \\
\text { Using Student Performance to Improve Outcomes }\end{array}$ \\
\hline O'Connor & 2015 & The Use of Poll Everywhere as an Assessment Tool \\
\hline $\begin{array}{l}\text { Pan, Ferrer-Vinent, and } \\
\text { Bruehl }\end{array}$ & 2014 & $\begin{array}{l}\text { Library Value in the Classroom: Assessing Student } \\
\text { Learning Outcomes from Instruction and Collections }\end{array}$ \\
\hline Petersohn & 2008 & $\begin{array}{l}\text { Classroom Performance Systems, Library Instruction, } \\
\text { and Instructional Design: A Pilot Study }\end{array}$ \\
\hline $\begin{array}{l}\text { Petzold, Winterman, } \\
\text { and Montooth }\end{array}$ & 2010 & $\begin{array}{l}\text { Science Seeker: A New Model for Teaching } \\
\text { Information Literacy to Entry-Level Biology } \\
\text { Undergraduates }\end{array}$ \\
\hline Rimland & 2013 & $\begin{array}{l}\text { Assessing Affective Learning Using a Student } \\
\text { Response System }\end{array}$ \\
\hline Rinto & 2013 & $\begin{array}{l}\text { Developing and Applying an Information Literacy } \\
\text { Rubric to Student Annotated Bibliographies }\end{array}$ \\
\hline Samson and McLure & 2007 & Library Instruction Assessment through $360^{\circ}$ \\
\hline Scales and Von Seggern & 2014 & $\begin{array}{l}\text { Promoting Lifelong Learning through Government } \\
\text { Document Information Literacy: Curriculum and } \\
\text { Learning Assessment in the Government Document } \\
\text { Information Literacy Program (GDILP) at Washington } \\
\text { State University }\end{array}$ \\
\hline Smale and Regalado & 2009 & $\begin{array}{l}\text { Using Blackboard to Deliver Library Research Skills } \\
\text { Assessment: A Case Study }\end{array}$ \\
\hline Spackman & 2007 & $\begin{array}{l}\text { Utilizing Focus Groups to Evaluate an Information } \\
\text { Literacy Program in a General Biology Course }\end{array}$ \\
\hline $\begin{array}{l}\text { Spievak and Hayes- } \\
\text { Bohanan }\end{array}$ & 2013 & $\begin{array}{l}\text { Just Enough of a Good Thing: Indications of Long } \\
\text { Term Efficacy in One-Shot Library Instruction }\end{array}$ \\
\hline Squibb and Mikkelsen & 2016 & $\begin{array}{l}\text { Assessing the Value of Course Embedded Information } \\
\text { Literacy on Student Learning and Achievement }\end{array}$ \\
\hline $\begin{array}{l}\text { Staley, Branch, and } \\
\text { Hewitt }\end{array}$ & 2010 & $\begin{array}{l}\text { Standardised Library Instruction Assessment: An } \\
\text { Institution-Specific Approach }\end{array}$ \\
\hline Stowe & 2013 & $\begin{array}{l}\text { Designing and Implementing and Information } \\
\text { Literacy Instruction Outcomes Assessment Programs }\end{array}$ \\
\hline
\end{tabular}


Outcomes Assessment in Undergraduate Information Literacy Instruction 469

\begin{tabular}{|c|c|c|}
\hline Strittmatter & 2012 & $\begin{array}{l}\text { Developing and Assessing a Library Instruction } \\
\text { Model for a Core Business Class }\end{array}$ \\
\hline Swoger & 2011 & $\begin{array}{l}\text { Closing the Assessment Loop using Pre- and Post- } \\
\text { Assessment }\end{array}$ \\
\hline Tewell and Angell & 2015 & $\begin{array}{l}\text { Far from a Trivial Pursuit: Assessing the Effectiveness } \\
\text { of Games in Information Literacy Instruction }\end{array}$ \\
\hline $\begin{array}{l}\text { Vance, Kirk, and } \\
\text { Gardner }\end{array}$ & 2012 & $\begin{array}{l}\text { Measuring the Impact of Library Instruction on } \\
\text { Freshman Success and Persistence: A Quantitative } \\
\text { Analysis }\end{array}$ \\
\hline $\begin{array}{l}\text { Victor Jr., Otto, and } \\
\text { Mutschler }\end{array}$ & 2013 & $\begin{array}{l}\text { Assessment of Library Instruction on Undergraduate } \\
\text { Student Success in a Documents Based Research } \\
\text { Course: The Benefits of Librarian, Archivist, and } \\
\text { Faculty Collaboration }\end{array}$ \\
\hline Walker and Pearce & 2014 & Student Engagement in One-Shot Library Instruction \\
\hline $\begin{array}{l}\text { Watson, Rex, Markgraf, } \\
\text { Kishel, Jennings, and } \\
\text { Hinnant, }\end{array}$ & 2013 & $\begin{array}{l}\text { Revising the 'One-Shot' through Lesson Study: } \\
\text { Collaborating with Writing Faculty to Rebuild a } \\
\text { Library Instruction Session }\end{array}$ \\
\hline $\begin{array}{l}\text { Zoellner, Samson, and } \\
\text { Hines }\end{array}$ & 2008 & $\begin{array}{l}\text { Continuing Assessment of Library Instruction to } \\
\text { Undergraduates: A General Education Course Survey } \\
\text { Research Project }\end{array}$ \\
\hline
\end{tabular}

\section{Notes}

1. Mary J. Snyder Broussard, "Using Games to Make Formative Assessment Fun in the Academic Library," Journal of Academic Librarianship 40 (2014): 35-42, doi:10.1016/j.acalib.2012.12.001; Esther S. Grassian and Joan R. Kaplowitz, Information Literacy Instruction: Theory and Practice (New York, N.Y.: Neal-Schuman Publishers, 2009), 6-8; Megan Oakleaf, "Dangers and Opportunities: A Conceptual Map of Information Literacy Assessment Approaches," portal: Libraries $\mathcal{E}$ the Academy 8 (2008): 233-53, available online at https://www.press.jhu.edu/journals/portal_libraries_and_ the_academy/ [accessed 14 May 2016]; Carolyn J. Radcliff, Mary Lee Jensen, Joseph A. Salem Jr., Kenneth J. Burhanna, and Julie A. Gedeon, A Practical Guide to Information Literacy Assessment for Academic Librarians (Westport, Conn.: Libraries Unlimited, 2007), 7-11; Brandy Whitlock and Julie Nanavati, "A Systematic Approach to Performative and Authentic Assessment," Reference Services Review 41 (2013): 32-48, doi:10.1108/00907321311300866.

2. Kornelia Tancheva, Camille Andrews, and Gail Steinhart, "Library Instruction Assessment in Academic Libraries," Public Services Quarterly 3 (2007): 29-56, doi:10.1300/J295v03n01_03. This shift in assessment is also discussed by Lynn Cameron, Steven L. Wise, and Susan M. Lottridge, "The Development and Validation of the Information Literacy Test," College \& Research Libraries, 68 (2007): 229-36, doi:10.5860/crl.68.3.229; Debra Gilchrist and Anne Zald, "Instruction and Program Design through Assessment," in Information Literacy Instruction Handbook, eds. Christopher N. Cox and Elizabeth Blakesley Lindsay (Chicago, Ill.: Association of College \& Research Libraries, 2008), 165; Megan Oakleaf, "Are They Learning? Are We? Learning Outcomes and the Academic Library," Library Quarterly 81 (2011): 61-82, available online at www.jstor.org/stable/10.1086/657444 [accessed 14 May 2016].

3. Grassian and Kaplowitz, Information Literacy Instruction, 200.

4. Megan Oakleaf, Michelle S. Millet, and Leah Kraus, "All Together Now: Getting Faculty, Administrators, and Staff Engaged in Information Literacy Assessment," portal: Libraries $\mathcal{E}$ the Academy 11 (2011): 832, doi:10.1353/pla.2011.0035.

5. Katherine Schilling and Rachel Applegate, "Best Methods for Evaluating Educational Impact: A Comparison of the Efficacy of Commonly Used Measures of Library Instruction," Journal of the Medical Library Association 100 (2012): 258-69, doi:10.3163/1536-5050.100.4.007.

6. Oakleaf, Millet, and Kraus, "All Together Now."

7. Kimberly Mullins, "Good IDEA: Instructional Design Model for Integrating Information Literacy," Journal of Academic Librarianship 40 (2014): 339-49, doi:10.1016/j.acalib.2014.04.012; Megan Oakleaf et al., "Notes from the Field: 10 Short Lessons on One-Shot Instruction," Com- 
munications in Information Literacy 6 (2012): 5-23, available online at www.comminfolit.org/index. php?journal=cil\& page=index [accessed 14 May 2016]; Kevin P. Seeber, "Using Assessment Results to Reinforce Campus Partnerships," College \& Undergraduate Libraries 20 (2013): 352-65, doi:10.10 80/10691316.2013.829366.

8. Megan Oakleaf and Neal Kaske, "Guiding Questions for Assessing Information Literacy in Higher Education," portal: Libraries \& the Academy 9 (2009): 277, doi:10.1353/pla.0.0046.

9. Oakleaf, "Dangers and Opportunities," 234.

10. Grassian and Kaplowitz, Information Literacy Instruction, 11-18.

11. Penny M. Beile, "Assessing an Institution-Wide Information Fluency Program: Commitment, Plan, and Purposes," Public Services Quarterly 3 (2007): 127-46, doi:10.1300/J295v03n01_07; Cameron, Wise, and Lottridge, "The Development and Validation of the Information Literacy Test"; Gilchrist and Zald, "Instruction and Program Design through Assessment," 164-65; Grassian and Kaplowitz, Information Literacy Instruction, 200-02; Joan R. Kaplowitz, Designing Information Literacy Instruction: The Teaching Tripod Approach (New York, N.Y.: Rowman \& Littlefield, 2014), 111-12; Leslie Murtha, Eileen Stec, and Marilyn Wilt, "Using Assessment as a Tool to Improve Learning: An IFLA Workshop," IFLA Journal 32 (2006): 294-309, doi:10.1177/0340035206074066; Megan Oakleaf, "The Information Literacy Instruction Assessment Cycle: A Guide for Increasing Student Learning and Improving Librarian Instructional Skills," Journal of Documentation 65 (2009): 539-60, doi:10.1108/00220410910970249; Megan Oakleaf, "Using Rubrics to Assess Information Literacy: An Examination of Methodology and Interrater Reliability," Journal of the American Society for Information Science and Technology 60 (2009): 969-83, doi:10.1002/asi.21030; Oakleaf, "Are They Learning?"; Oakleaf and Kaske, "Guiding Questions for Assessing Information Literacy"; Radcliff et al., A Practical Guide to Information Literacy Assessment, 11; Karen Sobel and Cassidy R. Sugimoto, "Assessment of Learning during Library Instruction: Practices, Prevalence, and Preparation," Journal of Academic Librarianship 38 (2012): 191-204, doi:10.1016/j.acalib.2012.04.004; Tancheva, Andrews, and Steinhart, "Library Instruction Assessment."

12. Helen Blanchett, Jo Webb, and Chris Powis, A Guide to Teaching Information Literacy: 101 Practical Tips (London, U.K.: Facet Publishing, 2012), under "Introduction," available online at www.facetpublishing.co.uk/title.php?id=046596\#.WA-rzlsrK2w [accessed 14 May 2016].

13. Schilling and Applegate, "Best Methods for Evaluating Educational Impact."

14. Sobel and Sugimoto, "Assessment of Learning during Library Instruction."

15. Association of College and Research Libraries, "Information Literacy Competency Standards for Higher Education," available online at www.ala.org/acrl/standards/informationliteracycompetency [accessed 11 June 2016].

16. Association of College and Research Libraries, “Objectives for Information Literacy Instruction: A Model Statement for Academic Libraries," available online at www.ala.org/acrl/standards/ objectivesinformation [accessed 11 June 2016].

17. Association of College and Research Libraries, "Characteristics of Programs of Information Literacy That Illustrate Best Practices: A Guideline," available online at www.ala.org/acrl/ standards/characteristics [accessed 11 June 2016].

18. Association of College and Research Libraries, "Framework for Information Literacy for Higher Education," available online at www.ala.org/acrl/standards/ilframework [accessed 11 June 2016].

19. "SU" denotes a subject term contained in the databases' controlled vocabulary; all other terms were searched as keywords. " $*$ " is the truncation notation in the EBSCOhost search interface.

20. Mary Snyder Broussard, Rachel Hickoff-Cresko, and Jessica Urick Oberlin, Snapshots of Reality: A Practical Guide to Formative Assessment in Library Instruction (Chicago, Ill.: Association of College and Research Libraries, 2014), 10-12.

21. Broussard, "Using Games to Make Formative Assessment Fun"; Broussard, Hickoff-Cresko, and Oberlin, Snapshots of Reality, 3-9; Gilchrist and Zald, "Instruction and Program Design through Assessment," 175-76; Grassian and Kaplowitz, Information Literacy Instruction, 207, 210; Kaplowitz, Designing Information Literacy Instruction, 112-16; Oakleaf and Kaske, "Guiding Questions for Assessing Information Literacy"; Whitlock and Nanavati, "A Systematic Approach to Performative and Authentic Assessment."

22. Broussard, "Using Games to Make Formative Assessment Fun"; Kaplowitz, Designing Information Literacy Instruction, 112-16.

23. Gilchrist and Zald, "Instruction and Program Design through Assessment," 175.

24. Broussard, “Using Games to Make Formative Assessment Fun”; Broussard, Hickoff-Cresko, and Oberlin, Snapshots of Reality, 4; Gilchrist and Zald, "Instruction and Program Design through Assessment," 176; Grassian and Kaplowitz, Information Literacy Instruction, 207, 210; Kaplowitz, Designing Information Literacy Instruction, 116-17; Oakleaf and Kaske, "Guiding Questions for Assessing Information Literacy"; Whitlock and Nanavati, "A Systematic Approach to Performative and Authentic Assessment." 


\section{Outcomes Assessment in Undergraduate Information Literacy Instruction 471}

25. Whitlock and Nanavati, "A Systematic Approach to Performative and Authentic Assessment."

26. Donald L. Kirkpatrick and James D. Kirkpatrick, Evaluating Training Programs: The Four Levels, 3rd ed. (San Francisco, Calif.: Berrett-Koehler Publishers, 2006); Jerilyn Veldof, Creating the One-Shot Library Workshop: A Step-by-Step Guide (Chicago, Ill.: American Library Association, 2006), 70-71.

27. Grassian and Kaplowitz, Information Literacy Instruction, 202-03; Esther S. Grassian and Joan R. Kaplowitz, "Information Literacy Instruction," in Encyclopedia of Library and Information Science, 3rd ed., eds. Marcia J. Bates and Mary Niles Maack (New York, N.Y.: CRC Press, 2010), 2434-035; Kaplowitz, Designing Information Literacy Instruction, 117, 123; Veldof, Creating the OneShot Library Workshop, 70-80.

28. Grassian and Kaplowitz, Information Literacy Instruction, 202; Grassian and Kaplowitz, "Information Literacy Instruction," 2434; Kaplowitz, Designing Information Literacy Instruction, 117; Veldof, Creating the One-Shot Library Workshop, 71-72.

29. Grassian and Kaplowitz, Information Literacy Instruction, 202; Grassian and Kaplowitz, "Information Literacy Instruction," 2434-35; Kaplowitz, Designing Information Literacy Instruction, 117; Veldof, Creating the One-Shot Library Workshop, 72-75.

30. Grassian and Kaplowitz, Information Literacy Instruction, 202-03; Grassian and Kaplowitz, "Information Literacy Instruction," 2435; Kaplowitz, Designing Information Literacy Instruction, 123; Veldof, Creating the One-Shot Library Workshop, 75-76.

31. Grassian and Kaplowitz, Information Literacy Instruction, 203; Grassian and Kaplowitz, "Information Literacy Instruction," 2435; Kaplowitz, Designing Information Literacy Instruction, 123; Veldof, Creating the One-Shot Library Workshop, 77-78.

32. Toni M. Carter, "Use What You Have: Authentic Assessment of In-Class Activities," Reference Services Review, 41 (2013): 49-61, doi:10.1108/00907321311300875; Amy Gustavson, “Using ILIAC to Systematically Plan and Implement a Library Information Literacy Assessment Program for Freshman Classes," Public Services Quarterly 8 (2012): 97-113, doi:10.1080/15228959.2012.661673. Gustavson refers to in-class worksheets and activities (defined here as performance measures) as authentic assessment.

33. Kaplowitz, Designing Information Literacy Instruction, 112-017; Oakleaf, "Dangers and Opportunities"; Beth Twomey, "Authentic Assessments: Praxis for the Distance Librarian," Journal of Library and Information Services in Distance Learning 9 (2015): 170-78, doi:10.1080/15332 90X.2014.946356.

34. Julie K. Gilbert, "Using Assessment Data to Investigate Library Instruction for First Year Students," Communications in Information Literacy 3 no. 2 (2009): 181-92, available online at http://www.comminfolit.org/index.php?journal=cil\&page=article\&op=view\&path\%5B\%5D =Vol3-2009AR10 [accessed 14 May 2016]; Laura K. Gross, Sheau-Hwang Chang, and Marcia Dineen, "Strengthening Information Literacy in a Writing-designated Course in the Mathematics Major," College \& Undergraduate Libraries 23 (2016): 56-78, doi:10.1080/10691316.2014.93368 9; Shannon M. Staley, Nicole A. Branch, and Tom L. Hewitt, "Standardised Library Instruction Assessment: An Institution-Specific Approach," Information Research 15 (2010), available online at www.informationr.net/ir/15-3/paper436.html [accessed 14 May 2016]; Bonnie J.M. Swoger, "Closing the Assessment Loop Using Pre- and Post-Assessment," Reference Services Review 39 (2011): 244-59, doi:10.1108/00907321111135475; Eamon C. Tewell and Katelyn Angell, "Far from a Trivial Pursuit: Assessing the Effectiveness of Games in Information Literacy Instruction," Evidence Based Library \& Information Practice 10 (2015): 20-33, doi:10.18438/B8B60X; Paul Victor Jr., Justin Otto, and Charles Mutschler, "Assessment of Library Instruction on Undergraduate Student Success in a Documents-Based Research Course: The Benefits of Librarian, Archivist, and Faculty Collaboration," Collaborative Librarianship 5 (2013): 154-76, available online at https:// digitalcommons.du.edu/collaborativelibrarianship/vol5/iss3/2/ [accessed 14 May 2016]; Kate Zoellner, Sue Samson, and Samantha Hines, "Continuing Assessment of Library Instruction to Undergraduates: A General Education Course Survey Research Project," College \& Research Libraries 69 (2008): 370-83, doi:10.5860/crl.69.4.370.

35. Grassian and Kaplowitz, Information Literacy Instruction, 209-12; Kaplowitz, Designing Information Literacy Instruction, 117, 125.

36. Schilling and Applegate, "Best Methods for Evaluating Educational Impact."

37. Ellysa Stern Cahoy and Robert Schroeder, "Embedding Affective Learning Outcomes in Library Instruction," Communications in Information Literacy, 6 (2012): 73-90, available online at www.comminfolit.org/index.php?journal=cil\&page $=$ article\&op=view \&path $\% 5 \mathrm{~B} \% 5 \mathrm{D}=\mathrm{v} 6 \mathrm{i} 1 \mathrm{p} 73$ [accessed 14 May 2016]; Emily Rimland, "Assessing Affective Learning Using a Student Response System," portal: Libraries \& the Academy 13 (2013): 385-401, doi:10.1353/pla.2013.0037.

38. Cahoy and Schroeder, "Embedding Affective Learning Outcomes."

39. Grassian and Kaplowitz, Information Literacy Instruction, 208-09; Kaplowitz, Designing 
Information Literacy Instruction, 125; Carol McCulley, "Mixing and Matching: Assessing Information Literacy," Communications in Information Literacy 3 (2009), 171-80, available online at www. comminfolit.org/index.php?journal=cil\&page=article\&op=viewArticle \&path\%5B $\% 5 \mathrm{D}=\mathrm{Vol} 3-$ 2009AR9 [accessed 14 May 2016]; Murtha, Stec, and Wilt, "Assessment as a Tool"; Radcliff et al., A Practical Guide to Information Literacy Assessment, 47-58; Schilling and Applegate, "Best Methods for Evaluating Educational Impact"; Tancheva, Andrews, and Steinhart, "Library Instruction Assessment"; Whitlock and Nanavati, "A Systematic Approach to Performative and Authentic Assessment."

40. Avril Cunningham, "Using 'Ready-to-Go' Assessment Tools to Create a Year Long Assessment Portfolio and Improve Instruction," College E Undergraduate Libraries, 13 (2006): 75-90, doi:10.1300/J106v13n02_06; Ignacio J. Ferrer-Vinent and Christy A. Carello, "Embedded Library Instruction in a First-Year Biology Laboratory Course," Science E Technology Libraries 28 (2008): 325-51, doi:10.1080/01942620802202352; Amy Gratz and Lee Twombly Olson, "Evolution of a Culture of Assessment: Developing a Mixed-Methods Approach for Evaluating Library Instruction," College E Undergraduate Libraries 21 (2014): 210-31, doi:10.1080/10691316.2013.829371; Sue Samson and Merinda McLure, "Library Instruction Assessment Through 360'," Public Services Quarterly 3 (2007): 9-28, doi:10.1300/J295v03n01_02; Sara Davidson Squibb and Susan Mikkelsen, "Assessing the Value of Course-Embedded Information Literacy on Student Learning and Achievement," College \& Research Libraries 77 (2016): 164-83, doi:10.5860/crl.77.2.164.

41. Ferrer-Vinent and Carello, "Embedded Library Instruction"; Ignacio J. Ferrer-Vinent and Christy A. Carello, "The Lasting Value of an Embedded, First-Year, Biology Library Instruction Program," Science E Technology Libraries 30 (2011): 254-66, doi:10.1080/0194262X.2011.592789; Linda Fuselier and Belle Nelson, "A Test of the Efficacy of an Information Literacy Lesson in an Introductory Biology Laboratory Course with a Strong Science-Writing Component," Science E Technology Libraries 30 (2011): 58-75, doi:10.1080/0194262X.2011.547101; Gilbert, “Using Assessment Data"; Donald L. Gilstrap and Jason Dupree, "Assessing Learning, Critical Reflection, and Quality Educational Outcomes: The Critical Incident Questionnaire," College E Research Libraries 69 (2008): 407-26, doi:10.5860/0690407; Gratz and Olson, "Evolution of a Culture of Assessment"; Marilyn M. Helms and Melissa Whitesell, "Transitioning to the Embedded Librarian Model and Improving the Senior Capstone Business Strategy Course," Journal of Academic Librarianship 39 (2013): 401-13, doi:10.1016/j.acalib.2013.03.015; Van Houlson, "Getting Results from One-Shot Instruction: A Workshop for First-Year Students," College \& Undergraduate Libraries 14 (2007): 89-108, doi:10.1300/J106v14n01_07; Corey M. Johnson, Carol M. Anelli, Betty J. Galbraith, and Kimberly A. Green, "Information Literacy Instruction and Assessment in an Honors College Science Fundamentals Course," College E Research Libraries 72 (2011): 533-47, doi:10.5860/crl-166; Elana Karshmer and Jacalyn E. Bryan, "Building a First-Year Information Literacy Experience: Integrating Best Practices in Education and ACRL IL Competency Standards for Higher Education," Journal of Academic Librarianship 37 (2011): 255-66, doi:10.1016/j.acalib.2011.02.018; Meagan Lacy and Hsin-liang Chen, "Rethinking Library Instruction: Using Learning-Outcome-Based Design to Teach Online Search Strategies," Journal of Information Literacy 7 (2013): 126-48, doi:10.11645/ 7.2.1778; Caitlin McClurg, Susan Powelson, Eddy Lang, Fariba Aghajafari, and Steven Edworthy, "Evaluating Effectiveness of Small Group Information Literacy Instruction for Undergraduate Medical Education Students Using a Pre- and Post-Survey Study Design," Health Information E Libraries Journal 32 (2015): 120-30, doi:10.1111/hir.12098; Rimland, "Assessing Affective Learning"; Samson and McLure, "Library Instruction Assessment through 360"; Elizabeth R. Spievak and Pamela Hayes-Bohanan, "Just Enough of a Good Thing: Indications of Long-Term Efficacy in One-Shot Library Instruction," Journal of Academic Librarianship 39 (2013): 488-99, doi:10.1016/j. acalib.2013.08.013; Squibb and Mikkelsen, "Assessing the Value of Course-Embedded Information Literacy"; Victor Jr., Otto, and Mutschler, "Assessment of Library Instruction"; Kevin W. Walker and Michael Pearce, "Student Engagement in One-Shot Library Instruction," Journal of Academic Librarianship 40 (2014): 281-90, doi:10.1016/j.acalib.2014.04.004; Zoellner, Samson, and Hines, "Continuing Assessment of Library Instruction."

42. Ferrer-Vinent and Carello, "The Lasting Value of an Embedded, First-Year, Biology Library Instruction Program"; Fuselier and Nelson, "A Test of the Efficacy of an Information Literacy Lesson"; Denise Pan, Ignacio J. Ferrer-Vinent, and Margret Bruehl, "Library Value in the Classroom: Assessing Student Learning Outcomes from Instruction and Collections," Journal of Academic Librarianship 40 (2014): 332-38, doi:10.1016/j.acalib.2014.04.011.

43. Cunningham, "Using 'Ready-to-Go' Assessment Tools"; Ferrer-Vinent and Carello, "The Lasting Value of an Embedded, First-Year, Biology Library Instruction Program"; Gratz and Olson, "Evolution of a Culture of Assessment"; Samson and McLure, "Library Instruction Assessment through $360^{\circ}$; Squibb and Mikkelsen, "Assessing the Value of Course-Embedded Information Literacy."

44. Lesley S.J. Farmer, Instructional Design for Librarians and Information Professionals (New York, 


\section{Outcomes Assessment in Undergraduate Information Literacy Instruction 473}

N.Y.: Neal-Schuman Publishers, Inc., 2011), 67, 74; Murtha, Stec, and Wilt, “Using Assessment as a Tool to Improve Learning"; Grassian and Kaplowitz, Information Literacy Instruction, 211.

45. Farmer, Instructional Design, 74; Murtha, Stec, and Wilt, "Using Assessment as a Tool to Improve Learning."

46. Farmer, Instructional Design, 74; Murtha, Stec, and Wilt, "Using Assessment as a Tool to Improve Learning"; Radcliff et al., A Practical Guide to Information Literacy Assessment, 72-73, 86-87; Kaplowitz, Designing Information Literacy Instruction, 125.

47. Shevaun E. Watson, Cathy Rex, Jill Markgraf, Hans Kishel, Eric Jennings, and Kate Hinnant, "Revising the 'One-Shot' through Lesson Study: Collaborating with Writing Faculty to Rebuild a Library Instruction Session," College \& Research Libraries 74 (2013): 381-98, doi:10.5860/crl12-255.

48. Elizabeth Spackman, "Utilizing Focus Groups to Evaluate an Information Literacy Program in a General Biology Course," Science \& Technology Libraries 27 (2007): 3-28, doi:10.1300/J122v27 n03_02.

49. Melissa Bowles-Terry, "Library Instruction and Academic Success: A Mixed-Methods Assessment of a Library Instruction Program," Evidence Based Library \& Information Practice, 7 (2012): 82-95, doi:10.18438/B8PS4D.

50. Kaplowitz, Designing Information Literacy Instruction, 125; McCulley, "Mixing and Matching."

51. Grassian and Kaplowitz, Information Literacy Instruction, 209; Tancheva, Andrews, and Steinhart, "Library Instruction Assessment."

52. McCulley, "Mixing and Matching"; Grassian and Kaplowitz, Information Literacy Instruction, 212; Schilling and Applegate, "Best Methods for Evaluating Educational Impact."

53. Megan Oakleaf, "A Roadmap for Assessing Student Learning Using the New Framework for Information Literacy for Higher Education," Journal of Academic Librarianship 40 (2014): 510-14, doi:10.1016/j.acalib.2014.08.001.

54. Andrea Brooks, "Maximizing One-Shot Impact: Using Pre-Test Responses in the Information Literacy Classroom," Southeastern Librarian, 61 (2013): 41-43, available online at http:// digitalcommons.kennesaw.edu/seln/vol61/iss1/6/ [accessed 14 May 2016].

55. McCulley, "Mixing and Matching"; Murtha, Stec, and Wilt, "Using Assessment as a Tool to Improve Learning"; Oakleaf, "Dangers and Opportunities"; Radcliff et al., A Practical Guide to Information Literacy Assessment, 89-90, 103-04; Karen Sobel and Kenneth Wolf, "Updating Your Tool Belt: Redesigning Assessments of Learning in the Library," Reference and User Services Quarterly 50 (2011): 245-58, available online at https://journals.ala.org/rusq/article/view/3965 [accessed 14 May 2016]; Whitlock and Nanavati, "A Systematic Approach to Performative and Authentic Assessment."

56. Pre-/post-test design is reported by: Jackie Belanger, Rebecca Bliquez, and Sharleen Mondal, "Developing a Collaborative Faculty-Librarian Information Literacy Assessment Project," Library Review 61 (2012): 68-91, doi:10.1108/00242531211220726; Jacalyn E. Bryan and Elana Karshmer, "Assessment in the One-Shot Session: Using Pre- and Post-Tests to Measure Innovative Instructional Strategies among First-Year Students," College \& Research Libraries 74 (2013): 574-86, doi:10.5860/crl12-369; Melissa R. Dennis, Rebecca M. Murphey, and Kristin Rogers, "Assessing Information Literacy Comprehension in First-Year Students," Practical Academic Librarianship 1 (2011): 1-15, available online at http://journals.tdl.org/pal [accessed 14 May 2016]; Margaret Fain, "Assessing Information Literacy Skills Development in First Year Students: A Multi-Year Study," Journal of Academic Librarianship 37 (2011): 109-19, doi:10.1016/j.acalib.2011.02.002; FerrerVinent and Carello, "Embedded Library Instruction"; Ferrer-Vinent and Carello, "The Lasting Value of an Embedded, First-Year, Biology Library Instruction Program"; Houlson, "Getting Results from One-Shot Instruction"; Ma Lei Hsieh and Hugh A. Holden, "The Effectiveness of a University's Single-Session Information Literacy Instruction," Reference Services Review 38 (2010): 458-73, doi:10.1108/00907321011070937; Barbara Petersohn, "Classroom Performance Systems, Library Instruction, and Instructional Design: A Pilot Study," portal: Libraries $\mathcal{E}$ the Academy 8 (2008): 313-24, doi:10.1353/pla.0.0007; Jacquelyn Petzold, Brian Winterman, and Kristi Montooth, "Science Seeker: A New Model for Teaching Information Literacy to Entry-Level Biology Undergraduates," Issues in Science \& Technology Librarianship 63 (2010): 49-58, doi:10.5062/F4ZW1HVJ; B. Jane Scales and Marilyn Von Seggern, "Promoting Lifelong Learning Through Government Document Information Literacy: Curriculum and Learning Assessment in the Government Document Information Literacy Program (GDILP) at Washington State University," Reference Services Review 42 (2014): 52-69, doi:10.1108/RSR-09-2012-0057; Maura A. Smale and Mariana Regalado, "Using Blackboard to Deliver Library Research Skills Assessment: A Case Study," Communications in Information Literacy 3 (2009): 142-57, available online at www.comminfolit.org/index. php?journal=cil\&page=index [accessed 14 May 2016]; Staley, Branch, and Hewitt, "Standardised Library Instruction Assessment"; Brook Stowe, "Designing and Implementing an Information Literacy Instruction Outcomes Assessment Program," College \& Undergraduate Libraries 20 (2013): 
242-76, doi:10.1080/10691316.2013.829363; Swoger, "Closing the Assessment Loop"; Tewell and Angell, "Far from a Trivial Pursuit"; Walker and Pearce, "Student Engagement in One-Shot Library Instruction." Post-post-test is reported by Fuselier and Nelson, "A Test of the Efficacy of an Information Literacy Lesson."

57. Scales and Von Seggern, "Promoting Lifelong Learning."

58. Staley, Branch, and Hewitt, "Standardised Library Instruction Assessment."

59. Scales and Von Seggern, "Promoting Lifelong Learning"; Dennis, Murphey, and Rogers, "Assessing Information Literacy Comprehension."

60. Johnson et al., "Information Literacy Instruction."

61. Radcliff et al., A Practical Guide to Information Literacy Assessment, 34.

62. McCulley, "Mixing and Matching"; Radcliff et al., A Practical Guide to Information Literacy Assessment, 35-39; Whitlock and Nanavati, "ASystematic Approach to Performative and Authentic Assessment."

63. Radcliff et al., A Practical Guide to Information Literacy Assessment, 42-43.

64. Oakleaf et al., "Notes from the Field."

65. Oakleaf, "Dangers and Opportunities."

66. Kaplowitz, Designing Information Literacy Instruction, 125; McCulley, "Mixing and Matching"; Oakleaf, "Dangers and Opportunities"; Radcliff et al., A Practical Guide to Information Literacy Assessment, 44-45; Schilling and Applegate, "Best Methods for Evaluating Educational Impact"; Whitlock and Nanavati, "A Systematic Approach to Performative and Authentic Assessment."

67. Belanger, Bliquez, and Mondal, "Developing a Collaborative Faculty-Librarian Information Literacy Assessment Project"; Stefanie R. Bluemle, Amanda Y. Makula, and Margaret W. Rogal, "Learning by Doing: Performance Assessment of Information Literacy across the First-Year Curriculum," College \& Undergraduate Libraries 20 (2013): 298-313, doi:10.1080/10691316.2013.829368; Carter, "Use What You Have"; Fain, "Assessing Information Literacy Skills Development"; Gustavson, "Using ILIAC"; Karshmer and Bryan, "Building a First-Year Information Literacy Experience"; Elizabeth O. Moreton and Jamie L. Conklin, "Closing the Loop on Nursing Library Instruction: Using Student Performance to Improve Outcomes," Medical Reference Services Quarterly 34 (2015): 113-21, doi:10.1080/02763869.2015.986805; Petzold, Winterman, and Montooth, "Science Seeker"; Scales and Von Seggern, "Promoting Lifelong Learning"; Watson et al., "Revising the 'One-Shot' through Lesson Study."

68. Activities reported by: Katherine Boss, Katelyn Angell, and Eamon Tewell, "The Amazing Library Race: Tracking Student Engagement and Learning Comprehension in Library Orientations," Journal of Information Literacy 9 (2015): 4-14, doi:10.11645/9.1.1885; Ferrer-Vinent and Carello, "Embedded Library Instruction"; Fuselier and Nelson, "A Test of the Efficacy of an Information Literacy Lesson"; Gustavson, "Using ILIAC"; Paul R. Hottinger, Natalie M. Zagami-Lopez, and Alexandra S. Bryndzia, "FYI for FYE: 20-Minute Instruction for Library Orientation," Reference Services Review 43 (2015): 468-79, doi:10.1108/RSR-03-2015-0018; Johnson et al., “Information Literacy Instruction"; Connie Strittmatter, "Developing and Assessing a Library Instruction Model for a Core Business Class," Journal of Business \& Finance Librarianship 17 (2012): 95-105, doi:10.1080/089 63568.2012.630645. SRS use reported by Mary J. Snyder Broussard, "Secret Agents in the Library: Integrating Virtual and Physical Games in a Small Academic Library," College \& Undergraduate Libraries 17 (2010): 20-30, doi:10.1080/10691310903584759; Karen Dearing, Sue Alexander, Sharon Parente, and Amy York, "Using a Student Response System to Obtain Real-Time Assessment of Bibliographic Instruction Sessions," Tennessee Libraries 56 (2006): 1-8, available online at www.tnla. org/?38 [accessed 14 May 2016]; Dennis, Murphey, and Rogers, "Assessing Information Literacy Comprehension"; Moreton and Conklin, "Closing the Loop on Nursing Library Instruction"; Katie O'Connor, "Interactive Library Instruction: The Use of Poll Everywhere as an Assessment Tool," Endnotes 6 (2015): 1-13, available online at http://www.ala.org/rt/sites/ala.org.rt/files/content/oversightgroups/comm/schres/endnotesvol6no1/Article-InteractiveLibraryInstruction.pdf [accessed 14 May 2016]; Petersohn, "Classroom Performance Systems, Library Instruction, and Instructional Design."

69. Belanger, Bliquez, and Mondal, “Developing a Collaborative Faculty-Librarian Information Literacy Assessment Project"; Elizabeth Choinski and Michelle Emanuel, "The One-Minute Paper and the One-Hour Class: Outcomes Assessment for One-Shot Library Instruction," Reference Services Review 34 (2006): 148-55, doi:10.1108/00907320610648824; Cunningham, “Using 'Readyto-Go' Assessment Tools"; Gustavson, "Using ILIAC."

70. Houlson, "Getting Results from One-Shot Instruction"; Scales and Von Seggern, "Promoting Lifelong Learning"; Watson et al., "Revising the 'One-Shot' through Lesson Study."

71. Gross, Chang, and Dineen, "Strengthening Information Literacy."

72. Karshmer and Bryan, "Building a First-Year Information Literacy Experience."

73. Gayla Byerly, Annie Downey, and Lilly Ramin, "Footholds and Foundations: Setting Freshman on the Path to Lifelong Learning," Reference Services Review 34 (2006): 589-98, 
doi:10.1108/00907320610716477.

74. Spievak and Hayes-Bohanan, "Just Enough of a Good Thing."

75. Farmer, Instructional Design, 75. (Farmer describes authentic assessment as "ill-defined.") Gilchrist and Zald, "Instruction and Program Design through Assessment," 174; Kaplowitz, Designing Information Literacy Instruction, 125, 127; Twomey, "Authentic Assessments."

76. Farmer, Instructional Design, 75; Twomey, "Authentic Assessments."

77. Kaplowitz, Designing Information Literacy Instruction, 125; McCulley, "Mixing and Matching"; Oakleaf, "Dangers and Opportunities"; Schilling and Applegate, "Best Methods for Evaluating Educational Impact"; Sobel and Wolf, "Updating Your Tool Belt"; Twomey, "Authentic Assessments"; Whitlock and Nanavati, "A Systematic Approach to Performative and Authentic Assessment."

78. Oakleaf, "Dangers and Opportunities"; Louise R. Fluk, "Foregrounding the Research Log in Information Literacy Instruction," Journal of Academic Librarianship 41 (2015): 488-98, doi: 10.1016/j.acalib.2015.06.010.

79. McCulley, "Mixing and Matching"; Schilling and Applegate, "Best Methods for Evaluating Educational Impact"; Tancheva, Andrews, and Steinhart, "Library Instruction Assessment."

80. Fluk, "Foregrounding the Research Log."

81. Farmer, Instructional Design, 75; Grassian and Kaplowitz, Information Literacy Instruction, 212-13; Kaplowitz, Designing Information Literacy Instruction, 125; McCulley, "Mixing and Matching"; Twomey, "Authentic Assessments"; Whitlock and Nanavati, "A Systematic Approach to Performative and Authentic Assessment."

82. Katelyn Angell, "The Application of Reliability and Validity Measures to Assess the Effectiveness of an Undergraduate Citation Rubric," Behavioral \& Social Sciences Librarian 34 (2015): 2-15, doi:10.1080/01639269.2015.996481; Belanger, Bliquez, and Mondal, “Developing a Collaborative Faculty-Librarian Information Literacy Assessment Project"; Char Booth, M. Sara Lowe, Natalie Tagge, and Sean M. Stone, "Degrees in Impact: Analyzing the Effects of Progressive Librarian Course Collaborations on Student Performance," College E Research Libraries 76 (2015): 623-51, doi:10.5860/crl.76.5.623; Carol Perruso Brown and Barbara Kingsley-Wilson, "Assessing Organically: Turning an Assignment into an Assessment," Reference Services Review 38 (2010): 536-56, doi:10.1108/00907321011090719; Carter, "Use What You Have"; Fuselier and Nelson, "A Test of the Efficacy of an Information Literacy Lesson"; Gilbert, "Using Assessment Data"; Katie Greer, "Connecting Inspiration with Information: Studio Art Students and Information Literacy Instruction," Communications in Information Literacy 9 (2015): 83- 94, available online at www.comminfolit.org/ index.php?journal=cil\&page=index [accessed 14 May 2016]; Gross, Chang, and Dineen, "Strengthening Information Literacy"; Helms and Whitesell, "Transitioning to the Embedded Librarian Model"; Johnson et al., "Information Literacy Instruction"; Kacy Lundstrom, Anne R. Diekema, Heather Leary, Sheri Haderlie, and Wendy Holliday, "Teaching and Learning Information Synthesis: An Intervention and Rubric Based Assessment," Communications in Information Literacy 9 (2015): 60-82, available online at www.comminfolit.org/index.php?journal=cil\&page=index [accessed 14 May 2016]; Petzold, Winterman, and Montooth, "Science Seeker"; Erin E. Rinto, "Developing and Applying an Information Literacy Rubric to Student Annotated Bibliographies," Evidence Based Library and Information Practice 8 (2013): 5-18, doi:10.18438/B8559F; Squibb and Mikkelsen, "Assessing the Value of Course-Embedded Information Literacy"; Strittmatter, "Developing and Assessing a Library Instruction Model"; Victor Jr., Otto, and Mutschler, "Assessment of Library Instruction."

83. Moreton and Conklin, "Closing the Loop on Nursing Library Instruction."

84. Angell, "The Application of Reliability and Validity Measures"; Belanger, Bliquez, and Mondal, "Developing a Collaborative Faculty-Librarian Information Literacy Assessment Project"; Booth et al., "Degrees in Impact"; Carter, "Use What You Have"; Gilbert, "Using Assessment Data"; Greer, "Connecting Inspiration with Information"; Gross, Chang, and Dineen, "Strengthening Information Literacy"; Lundstrom et al., "Teaching and Learning Information Synthesis"; Petzold, Winterman, and Montooth, "Science Seeker"; Rinto, "Developing and Applying an Information Literacy Rubric to Student Annotated Bibliographies"; Scales and Von Seggern, "Promoting Lifelong Learning"; Squibb and Mikkelsen, "Assessing the Value of Course-Embedded Information Literacy"; Victor Jr., Otto, and Mutschler, "Assessment of Library Instruction."

85. Belanger, Bliquez, and Mondal, "Developing a Collaborative Faculty-Librarian Information Literacy Assessment Project."

86. Jason M. Vance, Rachel Kirk, and Justin G. Gardner, "Measuring the Impact of Library Instruction on Freshman Success and Persistence: A Quantitative Analysis," Communications in Information Literacy 6 (2012): 49-58, available online at www.comminfolit.org/index. php?journal=cil\&page=index [accessed 14 May 2016].

87. Bowles-Terry, “Library Instruction and Academic Success"; Priscilla Coulter, Susan Clarke, and Carol Scamman, "Course Grade as a Measure of the Effectiveness of One-Shot Information 
Literacy Instruction," Public Services Quarterly 3 (2007): 147-63, doi:10.1300/J295v03n01_08.

88. Squibb and Mikkelsen, "Assessing the Value of Course-Embedded Information Literacy."

89. Jackie Belanger, Ning Zou, Jenny Rushing Mills, Claire Holmes, and Megan Oakleaf, "Project RAILS: Lessons Learned about Rubric Assessment of Information Literacy Skills," portal: Libraries \& the Academy 15 (2015): 623-44, available online at http://muse.jhu.edu/journals/pla/ summary/v015/15.4.belanger.html [accessed 14 May 2016]; Grassian and Kaplowitz, Information Literacy Instruction, 213-14; Megan Oakleaf, "Using Rubrics to Collect Evidence for DecisionMaking: What Do Librarians Need to Learn?" Evidence Based Library and Information Practice 2 (2007): 27-42, doi:10.18438/B8WS3W; Oakleaf, "Dangers and Opportunities"; Oakleaf, "Using Rubrics to Assess Information Literacy."

90. Belanger, Bliquez, and Mondal, “Developing a Collaborative Faculty-Librarian Information Literacy Assessment Project"; Farmer, Instructional Design, 77; Grassian and Kaplowitz, Information Literacy Instruction, 213-14; Oakleaf, "Using Rubrics to Collect Evidence"; Oakleaf, "Dangers and Opportunities"; Oakleaf, "Using Rubrics to Assess Information Literacy."

91. Belanger et al., "Project RAILS."

92. Claire Lee Holmes and Megan Oakleaf, "The Official (and Unofficial) Rules for Norming Rubrics Successfully," Journal of Academic Librarianship 39 (2013): 599-602, doi: 10.1016/j. acalib.2013.09.001.

93. Belanger, Bliquez, and Mondal, “Developing a Collaborative Faculty-Librarian Information Literacy Assessment Project"; Grassian and Kaplowitz, Information Literacy Instruction, 213-14; Oakleaf, "Using Rubrics to Collect Evidence"; Oakleaf, "Dangers and Opportunities"; Oakleaf, "Using Rubrics to Assess Information Literacy."

94. Angell, "The Application of Reliability and Validity Measures"; Boss, Angell, and Tewell, "The Amazing Library Race"; Lundstrom et al., "Teaching and Learning Information Synthesis"; Squibb and Mikkelsen, "Assessing the Value of Course-Embedded Information Literacy"; Rinto, "Developing and Applying an Information Literacy Rubric to Student Annotated Bibliographies."

95. Booth et al., "Degrees in Impact"; Boss, Angell, and Tewell, "The Amazing Library Race"; Brown and Kingsley-Wilson, "Assessing Organically"; Lundstrom et al., "Teaching and Learning Information Synthesis"; Rinto, "Developing and Applying an Information Literacy Rubric to Student Annotated Bibliographies."

96. Angell, "The Application of Reliability and Validity Measures"; Boss, Angell, and Tewell, "The Amazing Library Race."

97. Angell, "The Application of Reliability and Validity Measures"; Booth et al., "Degrees in Impact"; Brown and Kingsley-Wilson, "Assessing Organically"; Fuselier and Nelson, "A Test of the Efficacy of an Information Literacy Lesson"; Gilbert, "Using Assessment Data"; Gross, Chang, and Dineen, "Strengthening Information Literacy"; Helms and Whitesell, "Transitioning to the Embedded Librarian Model"; Lundstrom et al., "Teaching and Learning Information Synthesis"; Rinto, "Developing and Applying an Information Literacy Rubric to Student Annotated Bibliographies"; Squibb and Mikkelsen, "Assessing the Value of Course-Embedded Information Literacy"; Victor Jr., Otto, and Mutschler, "Assessment of Library Instruction."

98. Carter, "Use What You Have"; Boss, Angell, and Tewell, "The Amazing Library Race"; Katelyn Angell and Katherine Boss, "Adapting the Amazing Library Race: Using Problem-Based Learning in Library Orientations," College \& Undergraduate Libraries 23 (2016): 44-55, doi:10.10 80/10691316.2014.935547; Smale and Regalado, “Using Blackboard to Deliver Library Research Skills Assessment."

99. Gilbert, "Using Assessment Data."

100. Helms and Whitesell, "Transitioning to the Embedded Librarian Model."

101. Brian Lym, Hal Grossman, Lauren Yannotta, and Makram Talih, "Assessing the Assessment: How Institutions Administered, Interpreted, and Used SAILS," Reference Services Review 38 (2010): 168-86, doi:10.1108/00907321011020806.

102. Lym et al., "Assessing the Assessment"; Juliet Rumble and Nancy Noe, "Project SAILS: Launching Information Literacy Assessment Across University Waters," Technical Services Quarterly 26 (2009): 287-98, doi:10.1080/07317130802678936.

103. Cameron, Wise, and Lottridge, "The Development and Validation of the Information Literacy Test."

104. Ibid.

105. Irvin R. Katz, “Testing Information Literacy in Digital Environments: ETS's iSkills Assessment," Information Technology \& Libraries 26 (2007): 158-71, doi:10.6017/ital.v26i3.3271; Mary M. Somerville, Gordon W. Smith, and Alexius Smith Macklin, "The ETS iSkills Assessment: A Digital Age Tool," Electronic Library 26 (2008): 158-71, doi:10.1108/02640470810864064.

106. Somerville, Smith, and Macklin, "The ETS iSkills Assessment."

107. Sara Sharun, Michelle Edwards Thompson, Nancy Goebel, and Jessica Knoch, "Institutions Collaborating on an Information Literacy Assessment Tool," Library Management 35 (2014): 
538-46, doi:10.1108/LM-03-2014-0035; Nancy Goebel, Jessica Knoch, Michelle Edwards Thompson, Rebekah Willson, and Sara Sharun, "Making Assessment Less Scary: Academic Libraries Collaborate on an Information Literacy Assessment Model," College \& Research Libraries News 74 (2013): 28-31, available online at http://crln.acrl.org/ [accessed 14 May 2016].

108. Sharun et al., "Institutions Collaborating on an Information Literacy Assessment Tool"; Goebel et al., "Making Assessment Less Scary."

109. Sharun et al., "Institutions Collaborating on an Information Literacy Assessment Tool"; Goebel et al., "Making Assessment Less Scary."

110. This list does not apply to the ILAAP test, which is unique among the standardized instruments and subject to different strengths and weaknesses from those listed here.

111. Broussard, "Using Games to Make Formative Assessment Fun"; Gilchrist and Zald, "Instruction and Program Design through Assessment," 188-90; Grassian and Kaplowitz, Information Literacy Instruction, 215-16; Lym et al., "Assessing the Assessment"; Radcliff et al., Practical Guide to Information Literacy, 103-04.

112. Blanchett, Webb, and Powis, A Guide to Teaching; Belanger et al., "Project RAILS"; Gilchrist and Zald, "Instruction and Program Design through Assessment," 165-66; Grassian and Kaplowitz, Information Literacy Instruction, 199-202; Murtha, Stec, and Wilt, "Assessment as a Tool"; Oakleaf, "Information Literacy Instruction Assessment Cycle", Oakleaf, "Are They Learning?"; Oakleaf, "A Roadmap for Assessing Student Learning"; Oakleaf and Kaske, "Guiding Questions for Assessing Information Literacy"; Oakleaf, Millet, and Kraus, "All Together Now"; Oakleaf et al., "Notes from the Field"; Radcliff et al., Practical Guide to Information Literacy, 4-5; Sobel and Wolf, "Updating Your Tool Belt"; Whitlock and Nanavati, "A Systematic Approach to Performative and Authentic Assessment."

113. Farmer, Instructional Design, 16.

114. Sarah Reinbold, "Using the ADDIE Model in Designing Library Instruction," Medical Reference Services Quarterly 32 (2013): 244-56, doi:10.1080/02763869.2013.806859.

115. Mullins, "Good IDEA."

116. Oakleaf, "Information Literacy Instruction Assessment Cycle."

117. Ibid.

118. Angell, "The Application of Reliability and Validity Measures"; Angell and Boss, "The Amazing Library Race”; Belanger et al., "Project RAILS"; Bluemle, Makula, and Rogal, "Learning by Doing"; Brown and Kingsley-Wilson, "Assessing Organically"; Byerly, Downey, and Ramin, "Footholds and Foundations"; Carter, "Use What You Have"; Fain, "Assessing Information Literacy Skills Development"; Ferrer-Vinent and Carello, "The Lasting Value of an Embedded, First-Year, Biology Library Instruction Program"; Fuselier and Nelson, "A Test of the Efficacy of an Information Literacy Lesson"; Gilstrap and Dupree, "Assessing Learning, Critical Reflection, and Quality Educational Outcomes"; Gratz and Olson, "Evolution of a Culture of Assessment"; Greer, "Connecting Inspiration with Information"; Hsieh and Holden, "The Effectiveness of a University's Single-Session Information Literacy Instruction"; Johnson et al., "Information Literacy Instruction"; Lacy and Chen, "Rethinking Library Instruction"; Moreton and Conklin, "Closing the Loop on Nursing Library Instruction"; Pan, Ferrer-Vinent, and Bruehl, "Library Value in the Classroom"; Samson and McLure, "Library Instruction Assessment Through 360"; Scales and Von Seggern, "Promoting Lifelong Learning"; Squibb and Mikkelsen, "Assessing the Value of CourseEmbedded Information Literacy"; Staley, Branch, and Hewitt, "Standardised Library Instruction Assessment"; Swoger, "Closing the Assessment Loop"; Watson et al., "Revising the 'One-Shot' through Lesson Study"; Gustavson, "Using ILIAC"; Stowe, "Designing and Implementing an Information Literacy Instruction Outcomes Assessment Program." Gustavson describes her use of ILIAC in designing and revising programming and assessment, and Stowe reports using both ADDIE and ILIAC in her ILI program.

119. Cunningham, "Ready-to-Go Assessment"; Karshmer and Bryan, "Building a First-Year Information Literacy Experience"; McClurg et al., "Small Group Information Literacy Instruction"; Rinto, "Developing and Applying an Information Literacy Rubric to Student Annotated Bibliographies"; Smale and Regalado, "Using Blackboard to Deliver Library Research Skills Assessment." These five authors report use of the cycle of assessment generally.

120. Gilchrist and Zald, "Instruction and Program Design through Assessment," 169-88 passim; Grassian and Kaplowitz, Information Literacy Instruction, 208-09; Kaplowitz, Designing Information Literacy Instruction, 111-14; Oakleaf and Kaske, "Guiding Questions for Assessing Information Literacy"; Radcliff et al., Practical Guide to Information Literacy, 19, 25-141 passim; Whitlock and Nanavati, "A Systematic Approach to Performative and Authentic Assessment."

121. Farmer, Instructional Design, 76.

122. Kaplowitz, Designing Information Literacy Instruction, 128.

123. Gilchrist and Zald, "Instruction and Program Design through Assessment," 185-87.

124. Hsieh and Holden, "The Effectiveness of a University's Single-Session Information 
Literacy Instruction."

125. Smale and Regalado, "Using Blackboard to Deliver Library Research Skills Assessment."

126. Rimland, "Assessing Affective Learning."

127. Karshmer and Bryan, "Building a First-Year Information Literacy Experience"; Lacy and Chen, "Rethinking Library Instruction"; Lundstrom et al., "Teaching and Learning Information Synthesis"; Rinto, "Developing and Applying an Information Literacy Rubric to Student Annotated Bibliographies"; Squibb and Mikkelsen, "Assessing the Value of Course-Embedded Information Literacy."

128. Squibb and Mikkelsen, "Assessing the Value of Course-Embedded Information Literacy." Squibb and Mikkelsen are the only authors in this group discussing a course-embedded ILI program.

129. Beile, "Assessing an Institution-Wide Information Fluency Program"; Gilchrist and Zald, "Instruction and Program Design through Assessment," 177.

130. Grassian and Kaplowitz, Information Literacy Instruction, 202-03.

131. Twomey, "Authentic Assessments."

132. Beile, "Assessing an Institution-Wide Information Fluency Program"; Gilchrist and Zald, "Instruction and Program Design through Assessment," 177; McCulley, "Mixing and Matching"; Megan Oakleaf, "Writing Information Literacy Assessment Plans: A Guide to Best Practice," Communications in Information Literacy 3 (2009): 80-89, available online at www.comminfolit.org/ index.php?journal=cil\&page=index [accessed 14 May 2016]; Oakleaf and Kaske, "Guiding Questions for Assessing Information Literacy"; Reinbold, "Using the ADDIE Model"; Sobel and Wolf, "Updating Your Tool Belt"; Tancheva, Andrews, and Steinhart, "Library Instruction Assessment."

133. Belanger et al., "Project RAILS"; Holmes and Oakleaf, "Rules for Norming Rubrics"; Mullins, "Good IDEA"; Oakleaf, "Writing Information Literacy Assessment Plans"; Oakleaf, Millet, and Kraus, "All Together Now"; Oakleaf et al., "Notes from the Field"; Seeber, "Using Assessment Results."

134. Oakleaf, "Writing Information Literacy Assessment Plans"; Oakleaf and Kaske, "Guiding Questions for Assessing Information Literacy"; Seeber, "Using Assessment Results"; Sobel and Wolf, "Updating Your Tool Belt."

135. Angell, "The Application of Reliability and Validity Measures"; Angell and Boss, "The Amazing Library Race"; Belanger, Bliquez, and Mondal, "Developing a Collaborative FacultyLibrarian Information Literacy Assessment Project"; Bowles-Terry, "Library Instruction and Academic Success"; Brown and Kingsley-Wilson, "Assessing Organically"; Byerly, Downey, and Ramin, "Footholds and Foundations"; Carter, "Use What You Have"; Choinski and Emanuel, "The One-Minute Paper and the One-Hour Class"; Cunningham, "Ready-to-Go Assessment"; Fain, "Assessing Information Literacy Skills Development"; Fuselier and Nelson, "A Test of the Efficacy of an Information Literacy Lesson"; Gilbert, "Using Assessment Data"; Gratz and Olson, "Evolution of a Culture of Assessment"; Gustavson, "Using ILIAC"; Houlson, "Getting Results from One-Shot Instruction"; Hsieh and Holden, "The Effectiveness of a University's Single-Session Information Literacy Instruction"; Lacy and Chen, "Rethinking Library Instruction"; Lundstrom et al., "Teaching and Learning Information Synthesis"; McClurg et al., "Small Group Information Literacy Instruction"; Samson and McLure, "Library Instruction Assessment through 360"; Squibb and Mikkelsen, "Assessing the Value of Course-Embedded Information Literacy"; Stowe, "Designing and Implementing an Information Literacy Instruction Outcomes Assessment Program"; Rinto, "Developing and Applying an Information Literacy Rubric to Student Annotated Bibliographies"; Watson et al., "Revising the 'One-Shot' through Lesson Study."

136. Dennis, Murphey, and Rogers, "Assessing Information Literacy Comprehension."

137. Ferrer-Vinent and Carello, "Embedded Library Instruction"; Ferrer-Vinent and Carello, "The Lasting Value of an Embedded, First-Year, Biology Library Instruction Program"; Johnson et al., "Information Literacy Instruction"; Pan, Ferrer-Vinent, and Bruehl, "Library Value in the Classroom"; Petzold, Winterman, and Montooth, "Science Seeker."

138. Helms and Whitesell, "Transitioning to the Embedded Librarian Model"; Strittmatter, "Developing and Assessing a Library Instruction Model."

139. Greer, "Connecting Inspiration with Information"; Gross, Chang, and Dineen, "Strengthening Information Literacy"; Victor Jr., Otto, and Mutschler, "Assessment of Library Instruction."

140. Booth et al., "Degrees in Impact."

141. Oakleaf, "Are They Learning?"; Sobel and Wolf, "Updating Your Tool Belt."

142. Oakleaf, "Dangers and Opportunities"; Schilling and Applegate, "Best Methods for Evaluating Educational Impact."

143. Bluemle, Makula, and Rogal, "Learning by Doing"; Belanger, Bliquez, and Mondal, "Developing a Collaborative Faculty-Librarian Information Literacy Assessment Project"; Byerly, Downey, and Ramin, "Footholds and Foundations"; Coulter, Clarke, and Scamman, "Course Grade as a Measure of the Effectiveness of One-Shot Information Literacy Instruction." 
Outcomes Assessment in Undergraduate Information Literacy Instruction 479

144. Gratz and Olson, "Evolution of a Culture of Assessment"; Helms and Whitesell, "Transitioning to the Embedded Librarian Model."

145. Sobel and Sugimoto, "Assessment of Learning during Library Instruction."

146. Ibid.

147. Schilling and Applegate, "Best Methods for Evaluating Educational Impact"; Sobel and Sugimoto, "Assessment of Learning during Library Instruction."

148. Oakleaf, "Are They Learning?"; Sobel and Wolf, "Updating Your Tool Belt."

149. Sobel and Sugimoto, "Assessment of Learning during Library Instruction."

150. Lym et al., "Assessing the Assessment"; Oakleaf, "Dangers and Opportunities"; Oakleaf and Kaske, "Guiding Questions for Assessing Information Literacy."

151. Sobel and Sugimoto, "Assessment of Learning during Library Instruction." 